$$
\begin{gathered}
5 F 395 \\
B 3
\end{gathered}
$$





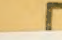

SF 395

B3

\section{HAND BOOK} Copy 1

ON

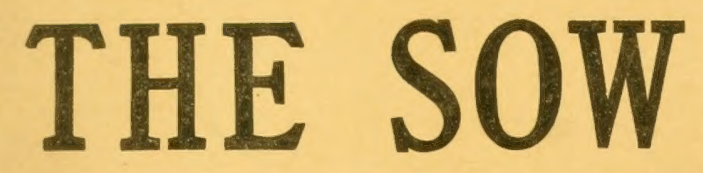

Queen of Farm Animals

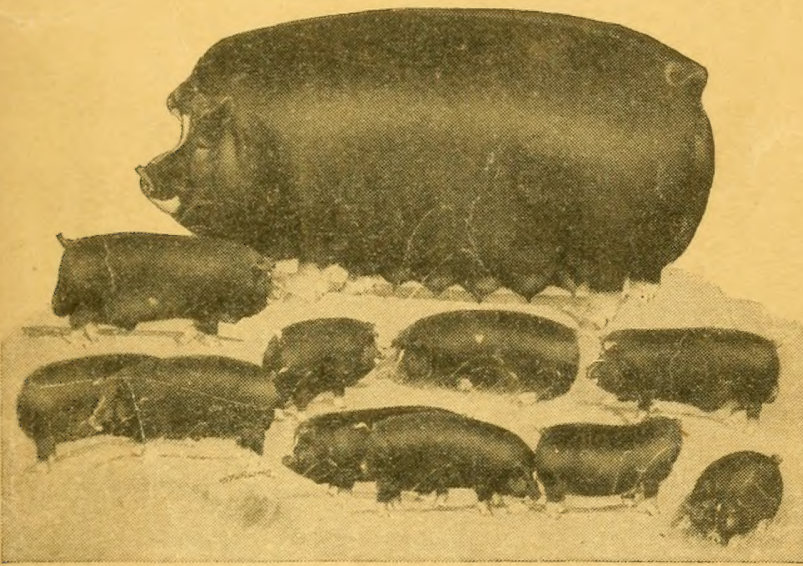

\section{PRACTICAL SCIENTIFIC TALK}

On How to Double Profits on Hogs

Evolution in Brood Sow Feeding, Worth Millions to U. S. Farmers

\section{By}

James Baynes, Editor American Swineherd 


\section{GESTATION TABLE FOR SOWS.}

PERIOD OF GESTATION, 113 DAYS.

\begin{tabular}{|c|c|c|c|c|c|c|c|}
\hline \multicolumn{2}{|c|}{$\begin{array}{l}\text { Time of } \\
\text { Service }\end{array}$} & \multicolumn{2}{|l|}{$\begin{array}{l}\text { Due to } \\
\text { Farrow }\end{array}$} & \multicolumn{2}{|l|}{$\begin{array}{l}\text { Time of } \\
\text { Service }\end{array}$} & \multicolumn{2}{|l|}{$\begin{array}{l}\text { Due to } \\
\text { Farrow }\end{array}$} \\
\hline January & $\begin{array}{l}1 \\
4\end{array}$ & April & $\begin{array}{l}22 \\
25\end{array}$ & July & $\begin{array}{l}3 \\
6\end{array}$ & October & $\begin{array}{l}23 \\
26\end{array}$ \\
\hline 6 & $\begin{array}{l}4 \\
7\end{array}$ & " & 28 & “ & $\begin{array}{l}0 \\
9\end{array}$ & " & $\begin{array}{l}20 \\
29\end{array}$ \\
\hline ! & 10 & May & 1 & $"$ & 12 & November & $r 1$ \\
\hline " & 13 & " & 4 & $"$ & 15 & " & 4 \\
\hline$a$ & 16 & $"$ & 7 & $"$ & 18 & " & 7 \\
\hline a & $\begin{array}{l}19 \\
29\end{array}$ & $"$ & 10 & $"$ & 21 & $"$ & 10 \\
\hline a & 25 & $"$ & 16 & 4 & 24 & " & 13 \\
\hline “ & 28 & " & 19 & “ & 30 & " & $\begin{array}{l}16 \\
19\end{array}$ \\
\hline " & 31 & “ & 22 & August & 2 & a & 22 \\
\hline February & 3 & $"$ & 25 & " & 5 & $"$ & 25 \\
\hline " & $\begin{array}{l}6 \\
9\end{array}$ & $"$ & 28 & " & 8 & December & 28 \\
\hline " & 12 & June & $\begin{array}{r}1 \\
3\end{array}$ & " & $\begin{array}{l}11 \\
14\end{array}$ & December & $\begin{array}{l}1 \\
4\end{array}$ \\
\hline " & 15 & " & 6 & " & 17 & “ & 7 \\
\hline " & 18 & " & 9 & " & 20 & " & 10 \\
\hline$"$ & 21 & $"$ & 12 & $"$ & 23 & $"$ & 13 \\
\hline$"$ & 24 & " & 15 & " & 26 & " & 16 \\
\hline " & 27 & $"$ & 18 & & 29 & " & 19 \\
\hline March & 2 & " & 22 & September & r 1 & " & 22 \\
\hline “ & $\begin{array}{l}5 \\
8\end{array}$ & $"$ & $\begin{array}{l}25 \\
28\end{array}$ & " & $\begin{array}{l}4 \\
7\end{array}$ & " & $\begin{array}{l}25 \\
29\end{array}$ \\
\hline " & 11 & July & 1 & " & 10 & " & 31 \\
\hline$"$ & 14 & " & 4 & " & 13 & January & 3 \\
\hline$"$ & 17 & $"$ & 7 & " & 16 & & 6 \\
\hline$"$ & 20 & " & 10 & $"$ & 19 & $"$ & 9 \\
\hline " & 23 & $"$ & 13 & " & 22 & “ & 12 \\
\hline$"$ & 26 & " & 16 & " & 25 & “ & 15 \\
\hline$"$ & 29 & $"$ & 19 & ", & 28 & $"$ & 18 \\
\hline April & 1 & $"$ & 22 & October & 1 & $"$ & 21 \\
\hline “ & $\begin{array}{l}4 \\
7\end{array}$ & 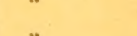 & $\begin{array}{l}25 \\
28\end{array}$ & " & $\frac{4}{7}$ & $"$ & 24 \\
\hline " & 10 & :" & 31 & " & 10 & $"$ & $\begin{array}{l}27 \\
30\end{array}$ \\
\hline$"$ & 13 & Aug. & 3 & " & 13 & February & 2 \\
\hline$"$ & 16 & 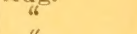 & 6 & " & 16 & " & $\overline{5}$ \\
\hline$"$ & 19 & $"$ & 9 & " & 19 & " & 8 \\
\hline “ & 2 & " & 12 & $"$ & 22 & $"$ & 11 \\
\hline 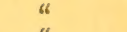 & 25 & " & 15 & " & 25 & " & 11 \\
\hline " & 28 & $"$ & 18 & $"$ & 28 & $"$ & 17 \\
\hline May & 1. & " & 21 & " & 31 & $"$ & 20 \\
\hline$"$ & 4 & $"$ & 24 & November & r 3 & 8 & 23 \\
\hline " & 7 & 6 & 27 & " & 6 & & 26 \\
\hline " & 10 & “ & 30 & $"$ & 9 & March & 1 \\
\hline " & 13 & September & \begin{tabular}{ll|l} 
& 2 \\
5
\end{tabular} & " & 12 & " & $\frac{4}{7}$ \\
\hline " & $\begin{array}{l}16 \\
19\end{array}$ & " & $\begin{array}{l}5 \\
8\end{array}$ & $"$ & $\begin{array}{l}15 \\
18\end{array}$ & " & 10 \\
\hline " & 22 & " & 11 & " & 21 & " & 13 \\
\hline " & 25 & " & 14 & " & 24 & $"$ & 16 \\
\hline " & 28 & " & 17. & " & 27 & $"$ & 19 \\
\hline " & 31 & “ & 20 & " & 30 & $"$ & 22 \\
\hline June & 3 & " & 23 & December & : 3 & $"$ & 25 \\
\hline a & 6 & $"$ & 26 & " & 6 & " " & 29 \\
\hline " & 9 & " & 29 & $"$ & 9 & A & 31 \\
\hline "s & 12 & $\underset{\text { October }}{\text { Octo }}$ & $\begin{array}{l}2 \\
5\end{array}$ & " & 12 & April & 3 \\
\hline " & 18 & " & 8 & " & 18 & " & $\begin{array}{l}0 \\
9\end{array}$ \\
\hline " & 21 & " & 11 & " & 21 & " & 12 \\
\hline " & 2 & " & 1 & $"$ & 24 & " & 15 \\
\hline u & 27 & " & 17 & 4 & 27 & 4 & 18 \\
\hline " & 30 & " & 20 & " & 30 & " & 21 \\
\hline
\end{tabular}




\section{Era of Improvement in Hog Business}

Most every farmer raises hogs, as one branch of his farm operation; 80 per cent of them, Prof. Dietrich of the Government Experiment Station says, waste one-fourth of their feed given to hogs, because they do not fully understand the feed question, or its importance in producing the greatest gain in the quickest time, at the least cost. It is not what the hog eats, but what he digests and assimilates, which are the proper proportions needed for maintenance and building the body by constructing bone and flesh. These requirements are correctly supplied by what is called the balanced ration. Two good feeds when combined are improved over either separate. Bread and butter is pretty good for man; butter alone would be unbalanced. As feed is about 90 per cent of the cost of producing pork, its importance is apparent.

When the cost of feed was on the basis of $18 \mathrm{c}$ corn per bushel and farm lands worth one-third their present price, it did not require the farmer to have the knowledge or give the consideration or attention to improved methods to secure a profit, which today are necessary under the changed conditions and prices.

The successful hog raisers have perfected a practical system of thoroughly tried out plans, that have given greatest profits, which are only on a par with the enterprise and wisdom of other upto-date business undertakings.

Scientific success in the hog business is readily attainable by any farmer who will equip himself with the knowledge of the practical methods of these successful farmers by careful reading of this book. The farmer who fails to post himself on the best proved plans for greatest profits in the hog business will be seriously handicapped under present new conditions of the times. This reading will prove interesting as well as instructive to all who have any interest in hogs and the more successful they are the better they will enjoy.it. The man who will study this line of thought is following the course of nature, furnishing seed for new thoughts, which grow and blossom into wisdom, which is real life, growth and progress.

The best results are attainable where each line is specialized and the experience from this concentrated thought and effort produces a costly, ripe wisdom which is free to the readers of this book. 


\section{The Brood Sow-The Mortgage Lifter}

The brood sow is one of the most valuable animals on the farm; she is seldom given the full credit that she deserves. If she is a good, prolific sow and is properly fed and cared for, no other farm animal can match her as a money-maker. She is the true mortgage lifter.

It is often claimed that the boar is half the herd; but without the assistance of the sow, he is a failure.

The annual increase of swine is from 500 to 1,000 per cent, with the possibility of doubling this, while that of cattle, sheep and horses are from 60 to 100 per cent. It therefore makes a difference whether the sow produces from 8 to 10 pigs twice a year, or only 3 to 5 twice a year, or perhaps 6 once a year. This shows the importance of selection, with proper management in breeding, feeding and caring for the sow. It is a simple business proposition to designate the profitable sow.

The brood sow is kept for profit; unlike the cow she cannot be used in a dairy, nor like a sheep with wool for shearing, nor is she used as a horse; her profit is wholly in her production of young. Raising pigs being her chief work, the management and care of her, to enable her to produce the largest number of well developed pigs, is strictly essential.

True, there is an inherited quality so far as prolificacy is concerned. An umprolific sow is unprofitable compared with one that will produce large litters. This is a trait similar to a cow that will produce 14 pounds of butter a week while another one can scarcely make five. It is an inherent characteristic, transferable to her young, that must be bred into her and maintained; but even with this natural qualification to produce large litters, much depends upon getting this service from her by the method of handling, feeding and caring for her to meet with the best success.

This work is intended to give to the readers the best experience of the most successful, practical breeders and feeders of the hog. This experience has been attained by them with years of efforts, at heavy expense in searching and testing out, then dropping and avoiding the errors of wrong feeding, handling or caring for the brood sow. The readers hereof, therefore get the benefit of this proven ripe experience and can step at once into this complete success without cost to them of either money or time, which must prove highly valuable to them. 


\section{Prolificacy}

The scientific plan of feeding and handling swine for greater profit will compel the herdsman to prune his herd of every unprolific sow, that is unable to give returns to compare with the profitable prolific sow. The unprofitable sow should be fed and consigned to the pork market so that she will not be bringing into existence a strain of inferior small litter breeders.

We sometimes hear a breeder state in praise of his boar that he is a getter of large litters, which adds to his value. This is a mistaken idea, as the sow controls the number of the litter, or the foundation for the litter, in the embryo for the fetus of the future pig. The boar should be strong enough in vitality to be able to impregnate each embryo for the future litter; this is as far as he can go in determining the number in the litter. If the sow only presents or has three embryo germs for impregnation, the male cannot increase the number. The only condition where he can influence the number in the litter, is where his vitality is not strong enough to enable him to impregnate all of the embryo contained by the sow. This makes the selection of the sow a matter of first importance.

There is no certain outward indication for judging the prolificacy of a sow prior to a trial. True, there are some points that are favorable and are always sought by the ones selecting the sow who have had experience in this line. We want a so:w that is going to be a good milker, as the early, rapid growth of the pigs depends upon this natural supply very greatly, and it makes quite a difference in their start if the mother is a good milker. We want a sow that is broad and roomy, long with good individuality, one that will make a large brood sow and a motherly looking animal. The sow should have at least ten perfect teats or more, with less than this number she should be discarded. The sow that makes no show of udder is seldom a good milker and should be rejected. She should be selected from a large litter, coming from a strain that has had a record for producing large litters regularly.

A very successful breeder who has made a specialty of breeding up a strain of prolific sows averaging 8 to 10 to the litter in a large herd of sows, gives as his version of the small litters that prevail sometimes among farmers. He believes they are caused by their selection in paying no attention to their dam's prolificacy. 
Because of the fact of a sow having three pigs in her litter it is more than likely that she will get them started better, pushed stronger, by concentrating all of her milk to the three, thus having an advantage over the sow with ten, dividing hers between her larger litter. The farmer does not register his animals or keep track of the litters as a breeder does, therefore when the farmer comes to pick out his sows for his brood animals, he looks for the best individuals regardless of the fact that they may be out of small litters; as it is quite likely that they will continue to keep up their first push to the front with extra growth and be of extra size at the time of their selection; taking her from among the gilts in this way, they have brought about a strain of hogs that often fail to produce half enough pigs, thus proving the reproduction of an inherent characteristic. This is neglect or carelessness in the selection, that might easily and readily occur because of the prominent growth given to the small litters individually.

This kind of selection should be guarded against and extra pains taken in picking out a sow that was from a big litter of a prolific strain. We have breeders of all breeds who make a specialty of prolificacy, and are very successful.

There is a point, which to go beyond, is as damaging as the small litter. How big a litter is most desirable? There is a difference in sows. With some sows eight is a large enough litter, while with other sows ten have all been good pigs and suckled to weaning time safely. Over this number it is not ordinarily safe to go. The strain on the sow with litters of 13 to 18 might occasionally be met, but we would much prefer to have the strength and efforts of the sow concentrated in a litter of 8 or 10 for greatest success and profit.

The condition of the sow, as well as the feeding, has its influence to a certain extent and much more with some sows than others.

For instance, sows that have been highly fitted for the shows are many times put in such a condition from their overfeeding and high flesh that they fail to breed. Experienced showmen always reduce the show sow in flesh immediately after the show and before attempting to breed her. But even the most successful and longest experienced are very frequently unable to have the sow breed and bring forth a litter after being highly fitted.

A herd of sows that are fed almost exclusively on a corn diet, are more or less subject to farrow 
smaller litters than the same animals do when fed upon a better balanced ration, by cutting out most of the corn. It not only influences the number of the litter, but the size and vitality of the pigs are unfavorably affected by the corn diet.

On the other hand, a highly protein feed balancing the ration with alfalfa and clover hay during the winter season when they cannot reach the pasture, is found to be one of the greatest aids. This feed fosters good size litters of strong constitution, of large pigs; as one breeder states that they seem to be a week old at farrowing time, so great is the difference. This clover or alfalfa hay can be fed either as a ground feed in a slop, or run through the cutting box and cooked in a heater, or fed as raw hay where it is properly cured. They wiil eat it with the greatest of relish.

Also oats and barley ground together make an especially choice feed for both the brood sow and the growing pigs. The feeding of the brood sow while she is carrying her farrow contemplates the feeding of the unfarrowed litter, which must have its growth from the proper feed essentials to contribute to the best results. Elsewhere in this book will be shown proper plans of feeding these various ingredients.

Every hog raiser should condemn to the pork market every sow that fails to farrow a good sized litter, unless through some fault outside of her inherited qualities. The sharp weeding out and feeding for the pork market is the aggressive method for improving and maintaining the full complement litter. This plan is enlisting more breeders and feeders continuously with satisfactory results.

The sow that farrows from three to five pigs twice a year, in some instances only once, costs nearly as much to maintain as the sow that produces ten pigs twice a year showing the extra profit in the latter, both in the amount of money invested and the cost of maintaining.

There are some sows that, although not so large nor as desirable as the best, give good results in the size of the litter and in raising them, because of the good milking qualities, something on the order of the Jersey cow, as milkers, which shows up in the good growth of the pig.

A good standard for everyone in selecting their brood sow is to get an animal that will mature into a $600-1 b$. sow or over, in fair flesh. There are 
sows that go to 800 pounds and over but they are not very plentiful. She should have plenty of quality with her size to give her the easy feeding characteristic that counts on the profitable side.

A very successful breeder states that he selects always from a prolific family and not too chunky type, but one of good length without coarseness, one that has a motherly look and is of a quiet disposition. Size with finish is the object desired and one should never be carried away with a pretty little dumpling. Be careful not to get one too loose and rangy in appearance, without good spring of ribs. The back should be arched a trifle, and have good width and continue arched when in farrow. The good mother carries with her good suckling qualities. $\mathrm{He}$ is opposed to making a severe cross of opposites.

He wants her to be broad between the eyes, with smooth coat, as "like produces like." The sow that is not too coarse is usually a mellow, easy feeding kind, one that you can depend upon her pigs being easy feeders. A yearling sow last year raised him a litter of eight pigs and she tipped the beam at 535 pounds upon weaning them and will mature into a 750-pound sow. She was one of the easy feeding kind.

It pays to retain year after year a good, large, motherly sow that has proven herself a reliable breeder, that can be depended upon to produce a big litter of good sized pigs regularly and raise them well with quick growth and early development.

The sow of this character improves with experience each year, at least until six or seven years old. She is usually worth two untried sows. A nervous, restless sow is undesirable, as she is so liable to trample upon her young pigs and kill them before they are able to take care of themselves.

Another virtue possessed by a sow of this kind is the fact that she has no difficulty in farrowing her litter, while a small or narrow bodied sow risks the life of her pigs and herself with each farrow.

Every hog raiser should qualify himself if not fully posted, with the best up-to-date knowledge to enable him to select correctly. Also to be able to handle, care and feed her in the best manner to attain the greatest success and largest profit from her, the same as a man in any other business or profession would expect to undergo. 


\section{Handling Sow After Breeding}

The natural condition of the sow has proven always the proper one to maintain. This is shown repeatedly by the bad results happening when it is overlooked. The sow needs all of the pure air that she can get; in good weather when there is sunshine she should have full access to both. Furthermore she needs exercise every day that the weather is suitable. Some of our best breeders practice turning their hogs out in the field and letting them roam over it if they have been properly fed; it gives them good exercise and a good opportunity to breathe pure air. Some breeders turn them into the cornstalk field and after picking up what pasture and overlooked corn they find, which they seem to appreciate searching for, they return to their feed lots and houses for the regular feed, shelter and beds for the night. This sunshine and exercise has a beneficial intluence on the unfarrowed litter.

After the sows are bred they should be fed a little stronger, which should be gradually increased, care being taken that the feed is a well balanced one; but little corn should be given. Oats and barley ground together and fed in a slop, or bran and middlings made into a slop, with clover or alfalfa hay, either ground or as hay, is an appropriate feed for the brood sow.

During the cold weather the feed should be cooked or heated. The benefit of this is seen.in both the growing pigs and brood sows. They show a real enjoyment for hot feed, whereas a cold feed in bitter weather is hurriedly eaten by them and when through they rush to their pens or sleeping places shivering, with their backs up, showing at least no pleasure or comfort in eating.

Of course there are days when the weather is stormy and disagreeable that it is better for them to be in their shelters than. outside. But the value of exercise has been so thoroughly established as an essential that it must be looked after if you want the best results.

Another point to always keep in view is the condition of the bowels of the sow. If she becomes constipated she will be out of condition quickly and liable to take disease, or get into worse condition continuously if it is not relieved at once. For this purpose a little oil cake meal, or tankage, or cracklings, given twice a week, is an excellent plan of correcting the bowel trouble, and maintaining a proper condition of the stomach for best results. 
This will prevent costiveness, which is always better than having to cure it. Constipation is the beginning of two-thirds of all diseases of men and animals. When the bowels are in right condition the body is fortified against disease.

It is the hog's nature to root in the ground, both for roots and worms, and it is provided therefore with a rooter. This natural desire can be satisfied in the winter season by feeding them tubers such as beets, rutabagas and the small, culled potatoes usually fed cooked. There may not be much feed value in them, but they help keep the bowels in proper condition for digesting other food.

While the sow should not be overfed at any time, which can be determined by her cleaning up her feed each meal, at the same time she should have sufficient so that she will not hunger or be driven to search for food to maintain herself, although moderate action to search for food after more than maintenance supply, is good for her.

The sow, when carrying her farrow, requires not only the ordinary maintenance food for herself, but must have sufficient in addition to produce the best growth for the unfarrowed litter. A failure in the sufficiency of the proper feed or imperfect feed is sure to have its influence on the coming litter, which will be shown in runts among the same.

It is desired that the sow should be so fed and handled that she will keep improving and gaining a little flesh continuously from the time that she is bred up to the time that she farrows her litter.

The brood sow's work is to produce the coming litter and therefore everything should be done that will be helpful to her in producing a large, strong constitutioned, healthy, well developed litter. Her condition and her feed has its direct influence in the realization of the best results to the coming litter.

The two best feeds for producing exceptionally large, fine, well developed litters of pigs are alfalfa or clover hay, and oats. Parties who have fed these feeds largely, with the addition of a small grain ration, have kept their sows in the best nattral condition and have raised the largest, finest, strongest, well developed litters.

Every hog raiser has to take into consideration the feeds that are accessible to him. Those that are grown upon the farm are first in importance, but it will pay any breeder or feeder to buy alfalfa hay or meal if he has not raised it upon the farm or has no clover hay as a substitute. 
This character of feeding with plenty of exercise and sunshine and pure water brings them down to the date of farrowing in the proper shape.

A few days before farrowing time successful hog men decrease the feed and supply something laxative so that the bowels will be in an easy condition as helpful to an easy farrowing.

If the sow farrows in the summer season she makes her nest out of doors and the first you are aware of her new family, she comes in with her litter and the exercise they get keeps them in the proper condition to take good care of themselves and avoid thumps.

But if it is cold weather care must be taken that the little pigs as farrowed, should have a basket with a hot brick wrapped up in blankets so that they are dried and placed around the brick; in a short time they are put to the sow and nature shows them what to do. The sow is only given warm water with bran sprinkled in it for the first twentyfour hours, then feeding commences slowly so as not to force the milk faster than it can be taken by the little pigs. If there is more milk than they can suckle, the udder is liable to become congested and what is known as caked udder occurs, and besides an injury to the sow, the milk is bad for the pigs and starts them to scouring, or it may, if caked, prevent them from getting any milk and they may starve, before you notice them, if not watched.

As the pigs grow, more feed should be given to the sow to sustain her and to produce the milk needed by the pigs, for it is a heavy drain upon her. The pigs should be allowed to follow the sow as soon as they are old enough to run around and the weather suitable, compelling them to take exercise in this way, thus avoiding thumps.

The readers of this book are respectfully referred and recommended to carefully study the instructive articles from the practical and successful breeders who have accomplished success because of their knowledge and practice.

The man who will consider carefully these methods and plans adopted by these men who reached the topmost round of success in their efforts can make it the reader's work, by thorough study and. absorbing the instructive directions, and in due course meet with the same successful results.

\section{Overfeeding the Sow}

Frequently parties buy a sow and are extremely anxious that she should make a great success and therefore do everything for her to help her accomplish this. 
In other words they are overdoing it. They overfeed her, keep her too close in her pen and are too apt to make a hot-house plant out of her. While she should be well fed, she should not be overfed; although she should be housed from the storms and provided with good, warm sleeping quarters, she needs the exercise, the air and the hustling that give her vigor and strength. In their desire to have her do well, they have by their overfeeding and extra precautions rendered it impossible for her to do so.

\section{Bone-Making Feed}

The brood sow requires an extra amount of bonemaking feed. She needs this for her young that she is growing and developing. The lack of it not only is an injury to the growing litter, but a damage to the sow herself and an aid in bringing on paralysis of the loins.

Frequently a litter when farrowed are deficient in bone. Some lacking in some parts, often the head. This should be avoided by giving good bonemaking material for the sow while developing her litter, both before and after farrowing.

By consulting the table you will find the feeds that have the ash in them strong, are the bonemaking, viz.: wood ashes, charred corn cobs, lime and bone meal are concentrated bone-making material. Wood ashes and charred corn cobs are always to be had. Look up your table of digestive nutriments in feeds in this book so as to regulate your feed to the brood sow.

\section{The Balanced Ration}

Balancing the ration is combining the feeds that will furnish the proper ingredients in the right proportions to nourish and develop all parts of the body of the animal without an excess of either portion which would be wasted.

Taking into consideration the results you desire to obtain, a properly balanced ration is one that will furnish these results. With young pigs or growing hogs it is necessary to have a bone builder and muscle former predominant; and for this reason corn, which has a smaller proportion of protein and a larger proportion of carbohydrates is not a good feed alone to grow muscle and produce bone for pigs or shoats.

A feeder asks, how shall we balance the ration? This depends somewhat on each particular person 
and his resources. For instance, the dairyman who has separator or skimmed milk, has a balance for corn or corn meal that is first class. It has proved best results when fed on the ratio of 3 to 5 pounds of milk to 1 pound of corn meal; that is, the best gains for the food consumed resulting from this proportion of the two ingredients. Buttermilk and whey are combined in the same proportions as skimmed milk.

One of the cheapest balancers of a grain ration is grass, alfalfa and clover being the two best of the grass feeds. Furthermore they can be used during the winter time through properly cured hay, which may be fed or run through a cutter first or ground into a meal and mixed into a swill. For best results a moderate quantity of grain should accompany the grass feed to bring about the proper balance. Of course you are required to take into consideration the size and demands of the animals that you are feeding to regulate the proportions.

As corn is rich in carbohydrates or fat forming ingredients and deficient in protein, one of the best grain balancers is wheat middlings, while shorts, rye, barley, peas or ground oats will also furnish a balance for the corn ration because of their richness in protein.

Some feeders use an equal amount of middlings with the corn ration, that is, half the ration is middlings and the other half corn. Some use onethird middlings and two-thirds corn. Others use two-thirds middlings and one-third corn; then again this is varied, feeding one preparation for a time, and then changing to the other. In balancing the ration with potatoes, beets, carrots or mangels, five pounds of these are fed to the one pound of corn meal. The feeder will have to use discretion and judgment as to quantity and proportion. Study the tables and it will be found that this combination feed will result beneficially both to the growing animals and the feeder.

It is shown that the younger the pigs or shotes are, the larger the proportion of protein should be. Begin with, say three-fourths middlings and onefourth corn, then as they grow older change to two-thirds middlings and one-third corn and when you come to the fattening peried you can use corn wholly.

Gluten meal, blood meal and digester tankage have a very high percentage of protein and are used with profit. 
As a bone builder pigs should have access to wood ashes, charcoal, charred cobs or bran and thus round out the balance requirements.

But few farmers realize the immense importance to them of clover or alfalfa upon their farm. Pigs should have a moderate feed of grain according to the size and demand of the animal with all the grass they will eat. Two proper feeds combined in right proportion of balance, increase the beneficial results over either separately.

Each feeder is compelled to take into consideration the feeds produced upon his farm as being the cheapest ordinarily, as there is no freight or transportation charges against them and the feeder gets his own profit from the feed produced.

It is difficult therefore to make an exact stated ration, as each. one will have to study from his standpoint a combination, to get the proper proportions of protein, carbohydrates, and succulence; then take into consideration the age and condition of the animal, whether growth is desired, or fat producing only, then regulate the same by studying the tables for the proportions of the ingredients of each feed as shown in this book.

The exercise of reasoning and studying by the feeder on these tables and on results desired, will be found beneficial to every feeder who will be surprised himself at the advantages that he will derive from this class by careful consideration.

For instance, you have to consider not only the proportions of the ingredients fed, but their cost, as you are running a business to make it a success and the cheaper the feed, if it is of the right character, the greater the profit. Therefore, we unhesitatingly recommend a careful reading of the methods and systems used by the able breeders and feeders who have articles in this book showing how they have reached success and are therefore good examples to pattern after.

\section{The Marvelous Alfalfa}

The hog raisers of the corn belt 20 years ago were unacquainted with the value of alfalfa as a swine feed, nor was it scarcely known that alfalfa could be grown east of the Rocky Mountains at that time; but today it flourishes in localities all over the United States. Wisconsin, Illinois, Iowa, Indiana, Ohio, Nebraska, Kansas and the real corn belt portions of the United States are growing alfalfa in various localities. 
Clover las long held prominence as the best forage plant for swine; but is compelled now to take second place as it is preceded by alfalfa. Pasture plant growth has been the surest method of cheapening hog feed during the growing season and it is but recently that alfalfa and clover hay cut at the proper time and cured properiy have been found to produce as beneficial results in the winter season as the grasses during the growing season. The cured hay shows the following digestible nutrients in $100 \mathrm{lbs}$; Alfalfa, 11.7 lbs. of protein, $40 \mathrm{lbs}$. carbohydrates and $1 \mathrm{lb}$. of fat. This is one-third more than clover in protein and a little more of carbohydrates and a little less fat and it places alfalfa hay almost the equal of wheat bran.

Alfalfa can be used as a pasture in the growing season for the sow and young pigs or the older pigs and is one of the cheapest feeds that can be supplied. As a sow feed during the winter season, fed either as hay or run through a feed cutter and then cooked, or ground by a mill into meal and fed in a slop, it is unequalled. It is one ingredient of the brood sow's ration that has proved of great value in keeping the sow in just the right condition of maintenance, and growing and developing the unfarrowed litter for the healthiest, strongest constitutioned pigs when farrowed. They are frequently reported as appearing a week old when farrowed compared with those that are fed a corn diet, and they continte this growth after farrowing when the sow is supplied with alfalfa feed right along. This makes alfalfa one of the most desirable feeds for the brood sow's maintenance and best growth of a litter that can be used. It is the balancer with a small grain ration that makes a cheap feed as well as a good feed which is the desirable point to make.

Of course, where alfalfa is not to be had, though many buy it in the bale or in the meal for feed, clover hay will take its place though not of equal value. It is good and can be used to good advantage in cheapening the grain ration.

Alfalfa is of inestimable value to the farmers of the corn belt, as well as of other portions of the United States and is growing and spreading over the country, as these facts become known and realized by the progressive farmers of our country.

It was proven by the trials of matured sows thin in flesh, that they would gain a half pound daily on alfalfa pasture without any grain. A well set vigorous field of alfalfa pasture will carry 15 to 25 pigs per acre. The number should never be large 
enough to pasture it down close, but should permit it to be of sufficient growth that the hay could be cut at intervals, so that the plant may be rejuve. nated thereby.

It was shown by the Kansas Experiment Station that rape and alfalfa produced 100 pounds of gain with practically the same grain allowance, and either feed when combined with grain gave better results than grain alone. One acre of alfalfa proved equal to two acres of rape.

Nebraska Station found that after sows weaned their pigs, they weighing 260 pounds and fed $8 \mathrm{I} / 2$ pounds of shelled corn each daily and grazing on alfalfa pasture, made 8 per cent larger gain than others fed 11 pounds of shelled corn daily in dry lots. A saving of 43 per cent in the amount of grain for 100 pounds of gain, due to the alfalfa pasture.

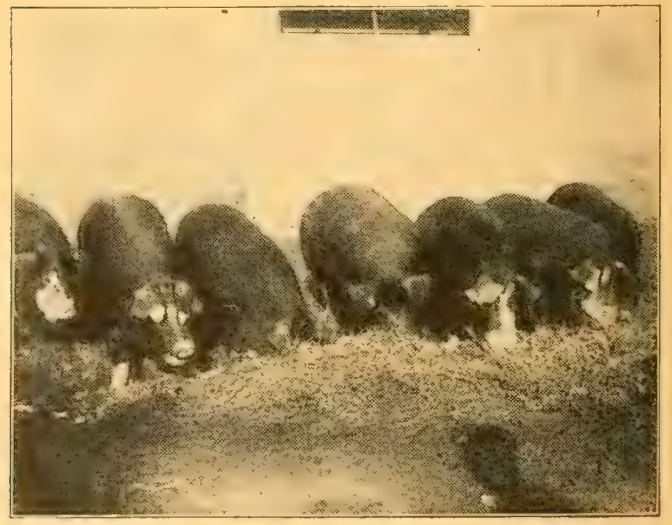

A bunch of Wisconsin brood sows eating alfalfa hay

Through the courtesy of the Wisconsin Agricultural University we publish this illustration from a photograph taken by them. Alfalfa is truly named by Prof. Moore of the Wisconsin University as the "Queen of Forage Plants." He states, "No other forage combines so many essentials of merit as alfalfa. No forage plant is more readily relished by farm animals, or exercises a more beneficial effect on the soil. Twenty-five thousand acres are now grown in the state of Wisconsin where twenty years ago it was almost an unknown plant." Ex-Governor Hoard of Hoard's Dairyman, was one of the first men to recognize the great importance of alfalfa as a forage plant for Wisconsin. 
Brood sows are wintered on third cutting of alfalfa hay, with a little skimmed milk, and no grain at all, until about two weeks before farrowing. Sows so maintained keep in good flesh, bear fine litters of strong, healthy pigs, and give an abundance of milk. The pigs are uniform, large, healthy, strong constitutioned and heavy boned; as one breeder expressed it, they seemed to be ten days old at farrowing time, from sows that received this sort of feed.

There is a difference in hay. It should be cut at a time when the leaves are supplied with the best strength of the plant before it has gone into the stems or seed.

\section{Danger Signals}

Constipation is one of the dangers that always threatens the herd and should be looked out for. Especially in the winter time when the feed is dry there is an inclination to become constipated. It does not take a costive animal long to get out of condition all over and ready to take on any disease around. It is the start that leads to so many troubles of the sow or pigs that it should be carefully prevented. A little oil cake meal in the feed or if necessary, a dose of salts should be given to start them up if they have become constipated, but prevention is better than a cure.

Where the alfalfa or clover hay is cut and cooked or soaked in hot water it usually furnishes a preventive, just as the succulent grasses do in the growing season.

Tankage or any oily matter is an aid to prevention. If you can't get oil cake meal, you can usually get linseed oil, as a little of this in the feed will start up the bowels.

Phosphate of lime is an essential feed very much needed by the brood sow carrying a litter or growing her pigs for bone building. We frequently have complaints of a sow farrowing a litter deficient in bone, not having had material enough in her feed to construct the bone for the growing pigs which then are virtually worthless. This can be supplied the sow in wood ashes, burned cobs, charcoal or bone meal or bran in the feed is an excellent bone builder. Consult the tables and use one of the articles of feed that gives them plenty of bone making material in ash and thus save the sow, improve the litter and prevent paralysis of the hind parts so often affecting the sow. 
Compel exercise of the sow while she is in farrow. She should, every day when the weather permits, be out in the field where she can roam around, pick up feed of some kind and get the necessary exercise for herself and her growing pigs. It makes strong, healthy pigs to keep the sow in this condition by plenty of exercise.

Alfalfa or clover hay in the winter season fed to the brood sow is almost invaluable. Of course it is accompanied by a small grain ration but little corn should be given to the brood sow. We have had breeders and successful feeders inform us that when they first discovered that sows were fed on alfalfa hay alone, they could not believe the reports of the herdsman that they had received but little feed outside of this hay. The pigs were so much larger and growthier, with such strong constitutions that they imagined it was some secret plan of feeding that had been adopted. Through their curiosity and desire to become posted spied on the feeder and proved it true and adopted it with the same success themselves.

Feed no rye either whole grain or ground to the brood sow carrying a litter for fear of her-getting ergot, which is so prevalent in rye grain, more so than any other as it is sure to produce abortion.

Be careful about forcing the flow of milk with the sow too soon before the little pigs are able to take care of it all. If the sow has too large a flow of milk and it is left in the udder it is liable to congest and cake and serious consequences result, both to the sow and the pigs. Read carefully the instructions herein of the breeders. For the first two or three days the sow needs but very little feed, bran in water the first day only.

If abortion that is contagious should get among the sows, they should be thoroughly disinfected and if at any time a sow aborts, the pigs and cleanirg should all be carefully taken away as well as the sow from the balance of the herd and then thoroughly disinfect the ground, flooring, bedding and the pens as well as the animals themselves to prevent the germ infecting the others.

The sow that is inclined or has the unnatural desire to eat her pigs shows that she is out of condition, that there is a craving demand for thisthat something has not been supplied that should have been. This is overcome by keeping the bowels free and furnishing cracklings or bone meal or tankage during pregnancy as a portion of the feed. If the desire is there, the only way to protect the 
pigs is to take them and with a woolen flannel dipped in kerosene, rub it over the hair of the pigs without getting it on the skin and this usually prevents her from eating the pigs.

Any sudden change of feed given the brood sow, suckling a litter, is liable to produce trouble with pigs; scours are often started this way. Make all clianges gradually.

Spoiled canned fruit given the sow is almost sure to be followed with diarrhea in the pigs and quick death if not checked.

Meat Brine-Salt in moderate quantities promotes digestion and the general health of the animal; but in too large quantities it deranges the stomach and bowels, causing the formation of gas in the stomach and bowels, diarrhea, vertigo, convulsions and paralysis and death in from 8 to 24 hours. The mucous membrane of the stomach and bowels are found after death highly infected and inflamed, and in some cases the brain is congested.

If a pig should get too much brine or salt in any form, it is best to give it an emetic. A tablespoonful of mustard stirred up in a half pint of warm water will answer the purpose. Then give two grains of opium in a little sweet oil or melted lard every two hours to relieve pain. If the animal is thirsty give it water in which has been put barley, slippery elm bark or gum arabic. This will assist in relieving the pain and inflammation. If there is severe diarrhea, add five grains of acetate of lead to the opium. In paralysis give one teaspoonful each of spirits of nitric ether and aromatic spirits of ammonia in half a glass of cold water every hour until better. If there should be constipation give two ounces of castor oil.

Ofttimes the water from cooking or boiling salted ham, pork or beef made into slop, has taken off pigs; and their owners were at a loss to account for their sudden death which is from the same cause as the meat brine.

Bloat is caused from turning hogs into fresh clover for the first time, when the dew is on, and especially when they are hungry; they gorge themselves with the fresh clover or alfalfa. It forms, a gas in the stomach that in a few hours is fatal to the hogs. It is usually too late to supply a remedy. If you find them suffering, they should be run and made to jump over a bar or rail, so that when they come down suddenly on their fore feet, it expels the gas from their throats and relieves them. The better plan is prevention. Turn 
your hogs into a clover field for the first time when the dew is off and after they have been fed a good feed at home of slop, so that they will eat but little; leave them in pasture but a few hours the first day; the second day this can be increased to double the length of time; the third day another fourth added and on the fifth day they will be accustomed to it and will not have any further trouble from the gas.

Cockleburs when they first start up in the spring are relished by the pigs, liking the fresh plant; but it carries a poison with it that will kill them. Besides when the seed bursts the sprouts lift up the old hull, the pigs in biting off the plant take this hull with it into their stomachs, and it forms into a hard ball that is indigestible and impassable through the bowels and causes quick death. It is necessary to keep them off of fields where cockleburs grew the previous year as they are sure to come up again.

Cottonseed meal is an excellent feed for cows to produce milk and for fattening steers, but there is some quality that chemists have not been able to discover that makes it dangerous as a pig feed, where it is continued for several weeks at a time. Breeders and feeders throughout the country who have feed cottonseed meal for periods, were mystified at sudden deaths of their animals.

In some parts of Texas and the south they have found a plan of feeding it safely in swill, where it is left to stand twenty-four hours before feeding. They feed with safety in this manner and have done so in some herds which established the truth that it can be done. Northern feeders have not persisted in the use of cottonseed meal since it was determined injurious when fed in the ordinary way.

\section{Changing Feed}

Care should always be exercised in making a change of feed, as a sudden change of feed ofttimes causes disorder of the bowels. It frequently brings on scours or dysentery that causes a loss of flesh and with the pigs suckling a sow, it is liable to produce scours that are quickly fatal if a renecty is not at once applied.

Therefore we say be careful in making a change. It should be done gradually and not an abrupt change at once. By only making a partial change, increasing it each day, can it be accomplished without bad results. Some breeders make a practice of using the kitchen swill in feeding their sows. This should not be done when the sow is suckling a 
litter, as there is too often canned fruits that are spoiled, or decayed vegetables which if given to the sow acts immediately upon the suckling litter and causes a deranged stomach, frequently resulting in scours or stomach troubles, which are either fatal or damaging to the growing litter.

These sudden changes should be avoided and likewise the kitchen swill should not go to the sow that is raising a young litter.

\section{Sows Disowning Pigs}

At times the sow refuses to acknowledge her pigs. This is generally caused by the sow being out of condition. She has fever frequently caused by constipation which puts her out of sorts with herself and her litter. A well known breeder states his plan as follows: "In regard to a young sow not owning her pigs, I had a fine gilt that wholly refused to acknowledge her pigs. It made her furious to have them around. I took them away from her as fast as they came and when she was through let her rest an hour, then put the pigs to her. She got up and danced around and would have killed all the pigs in a short time. I took them away and nailed a two-by-four scantling across the pen, 15 inches above the flooring, then with a cotton cord tied one front and one hind leg to it and brought her down on her side with her under legs tied. I put the pigs to her and she then showed signs of repentance. I kept her in this position most of the time for 36 hours, then tried her without and she behaved as nicely from that time on as any sow, and the pigs were as nice as ever on the place. I managed a similar case five years previous the same way with the same success. B. L. Gosick, Iowa."

\section{Comparison of Farm Animals}

Comparing swine with other farm animals we find the hog is favored.

The annual increase of the horse, cow and sheep run from 60 to 100 per cent.

While the annual increase of the hog is from 500 to 1,000 per cent with a reasonable possibility of 2,000 per cent.

The sow brings forth her litter twice a year, while the other farm animals bring their foals, calves and lambs but once a year. This places the sow far in advance in per cent of increase over all other farm animals. 
Dr. Warrington in "Chemistry on the Farm," states that of each 100 pounds of feed consumed, the gains are: For cattle, 9 pounds; sheep, 11 pounds, and pigs, 23 pounds; or pigs make nearly two and a half times as much gain from a given amount of feed as cattle. This shows the great value of hogs, on the farm for profit to the farmer and for this reason the hog has been given the title of "rent payer and mortgage lifter."

The hog can sell the farmer's corn, grain and grass through his stomach at a better price than any other animal on the farm. This makes the pig a desirable farm animal, not only because of the fact that he can convert more pounds of meat out of a given quantity of feed, but because he can he marketed quicker, than any other animal and as quickly as a crop of grain. The live stock farmer, therefore, builds up his farm instead of depriving it of its fertility by selling the produce off the farm.

\section{Money in Water}

Water is a necessity for the health and growth of the pig. It is the cheapest essential ingredient that enters in building the growth or maintaining the pig. At the same time it is an easy conveyor of diseases if the water is impure, stagnant or filthy. This shows the necessity of having pure clean water for the benefit of the health of the pigs. An unhealthy pig is a loss from the start and everything should be done to prevent it from becoming diseased through every channel.

A thirsty pig worrying for drink is a waste of energy, strength and flesh. Therefore they should be supplied with clean pure water all that they will naturally drink. Water is an aid to digestion and is helpful in every way, because of the large per cent of water in the make-up of the body of the animal. It helps the machine that transforms the different ingredients of feed into the new form of bone, muscle and blood. Water enters very largely into the gain of the growing and fattening hogs and since it is usually inexpensive compared with other ingredients in the make-up of the hog it should be supplied sufficient for all of its wants to increase the profits.

\section{Milk in Feed}

The sow's milk is a natural balanced ration. It contains double the solids of skimmed milk from the cow and $5 \frac{1}{2}$ times as much as is found in separator milk. 
The mineral and bone-growing elements will be one-fifth to one-sixth greater showing the necessity of securing a full supply of this kind of feed.

The young sow must and does, when properly fed, provide in her milk a larger amount of dry matter for growth of her young than a dairy cow three times her weight. This shows the benefits for best results to extend the time of nursing to its full limit of 10 to 12 weeks. All should know therefore how and what to feed the sow in order to maintain her vigor and produce the quality and quantity of milk that will cause the greatest and best growth of the pigs.

The milk of the sow is without exception the richest of all farm animals.

In weaning pigs at the early age of 6 "to 7 weeks care should be taken in supplanting nature with other animal milk, destitute of the elements above mentioned. You should commence to add daily for each pig about two ounces of finely ground grain, middlings with some boiled flaxseed to supplant the fat or oil cake meal, feeding them no more than they will eat up clean and leave them hungry for their next meal. It is best to feed three or four times a day and this process should be gradually adopted to introduce this feeding before weaning them, as abrupt or sudden changes in feed are accompanied usually with bad results.

After pigs have been fully weaned, give middlings, ground grain and barley or oat meal at rate of one pound to four pounds of milk and one ounce of oil meal added per pig.

It should be remembered that separator skimmed milk and buttermilk have only the water and casein left, being void of fat which acts as a heater and lubricator.

When deprived of these, and milk is fed exclusively, as a rule constipation will ensue, which later will be followed by piles, paralysis or some trouble.

Buttermilk should not be given in large quantities to a sow that is nursing pigs. It may affect her milk, causing it to curdle prematurely in the stomach of the young pigs, causing their death. If fed at all, the quantity should not exceed four pounds to a barrel of swill. If buttermilk from the creamery becomes an acid before it can be fed, better avoid feeding it. A four months old pig will do better and give best results if given four quarts of milk in 2 or 3 rations daily with the addition of the grain feed prescribed herein. 
Do not stuff growing pigs with too much milk more than can be digested and assimilated as it causes dyspepsia.

One of the good feeds or a large portion of the ration for the sow that is carrying the litter, or for the growing pigs, is alfalfa and clover meal produced by grinding the hay. This is a bone grower, a filler and brings about most excellent results and is relished by the pigs. The sows can be fed either clover or alfalfa hay or hay run through a cutter and heated in hot water mixed with a little meal feed. Ground oats is especially good as one of the grains, or it can be ground in the Duplex mill to a flour and fed in the mixture of milk or hot water to the little pigs perhaps better than any other way and is a most excellent feed as well as cheap. Read the articles from the successful, practical breeders in this book for further information on this line.

\section{Partial Paralysis of the Hind Legs}

This is a very common disease in sows, especially in fine bred pigs.

I have investigated this derangement and find it is caused by a want of sufficient phosphate of lime in the nerve system, especially the nerves supplying the hind legs. It is a known fact that the bones and nerves of pregnant animals are deficient in phosphate of lime on account of the drain on the system for phosphate to build up the foetus, and also to nourish the young after they are born. There seems to be more of a drain for phosphate on the system of the sow than any other female animal. The sow is more frequently affected with partial paralysis a few weeks after farrowing, although the derangement may occur before farrowing.

To prevent this trouble, the sow should be fed on ground oats, bran and oil meal, and as much milk as possible, during pregnancy, and while suckling young pigs. Should the trouble occur at either of the above mentioned periods, the following treatment should be begun as soon as the animal shows the first symptoms of weakness in the hind legs, or knuckling over at the fetlock joints. Of course, cases can be cured even after the animal is down and cannot get up. Give one tablespoonful of cod liver oil, 15 grains phosphate of lime and three drops of the fluid extract of nux vomica in a little food as a dose twice a day. This treatment should be continued for several weeks if needed.

Through experience it has been found that pigs from a sow that has had an attack of partial 
paralysis are no more likely to be attacked by the disease than pigs from a sow that has never had the disease.

A sow that is affected with partial paralysis does not seem to suffer any pain, indicating that the disease is a local one, and if the animal can be fattened while in this condition the flesh would be fit to be sold for pork.-D. McIntosh, V. S., Champaign, Ill.

\section{Selecting and Care of Sow}

The following article is from Henry Dorr, Remsen, Iowa, who is engaged in the breeding of big bone, big litter, pure bred Poland Chinas under the firm name of Henry Dorr \& Sons. Mr. Dorr is acknowledged by all who know him to be one of the prominent, successful breeders and developers of swine. His opinion and practice are recognized as the road to success in the hog business, and all are anxious to avail themselves of his knowledge. IVe take pleasure in presenting from his own hand the following:

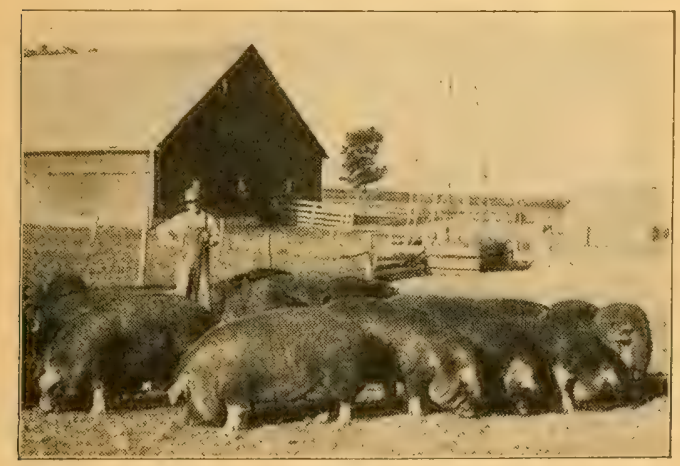

\section{A lot of Dorr's yearling sows}

"In selecting my brood sow I look for a good, uniform, growthy litter, where the dam is a good suckler, a good feeder, and of a gentle disposition.

"I want her to have good length, an arched back, good full hams, full around the heart, rather thin in neck, broad head, indicating intelligence, a slightly dished face, indicating early maturity. Ears should be well set apart, medium in size, and not break too close to head, so as to not cover the eyes. Her legs should be well set apart, out on each corner, be straight, showing a good strong heavy bone, pastern very short, and toes close together. I always look for ten or twelve well-developed teats, indicating 
both prolificness and the ability to properly nourish a good litter.

"I always keep my cye on the gilts showing a good appetite, as they are usually the fastest growers and make the best brood sows. A sow nursing eight to ten pigs must have a good appetite to furnish plenty of milk for her litter.

"After my gilts are selected for breeding purposes, they are let run on alfalfa or clover pasture, with some light slop of ground oats and wheat, with a little corn; enough of this is fed to keep them growing a good frame, but have them hungry enough to be out in the pasture most of the time. After harvest they have the run of the stubblefield, and as soon as the pumpkins are ripe we feed them all they want by just cracking them.

"About a month before breeding we start feeding them heavier and try to have them in pink of condition when we start to breed. We make an effort to breed them the second day in heat and allow only one service.

"After service we keep the sow alone until out of heat. We do not feed any slop through the breeding season until most of the sows are safely bred, when we gradually start on slop of ground oats and wheat and cut alfalfa mixed thick. In cold weather we feed some corn. Our aim is to keep them in good growing condition and not fail to give them exercise. We keep before them all the time a mixture of 20 lbs. of ashes, $4 \mathrm{lbs}$. of salt and $1 \mathrm{lb}$. of phosphate of lime. We try to keep our sows gentle, as kindness goes a long way with the brood sow.

"After winter sets in and snow is on the ground we use the road-drag and make runs for them, scatter corn fodder or sheaf oats along the runanything to keep them moving around, as exercise keeps them healthy and assures a good strong litter.

"We learned, many years ago, that to get a good strong litter of growthy pigs we must start to feed them through their dam before born.

"If a brood sow is fed nothing but corn she will become lazy and just move around enough to get her feed, and then go back to the sleeping quarters. She may look nice and sleek and pleasing to the eye, but she will not bring those robust, strong pigs that her sister will who had to hustle more for her living. A few days before she is due to farrow she is put in a pen by herself through the night, but 
in the daytime is let out for exercise. After she makes her nest we make it a point to be around day and night. If the weather is cold we fill a jug of hot water wrapped in a gunny-sack. As soon as the little fellows arrive we wipe them dry, mark them and put them in a barrel, where they soon get close to the warm jug; after all arrive we put them with the sow and see that each one gets a good fill. A.fter this they are put back in the barrel again for an hour, when they are put to the sow again. We do this the first half day, or until the sow is all through cleaning and lays quiet, then we let the pigs with the sow, unless the sow shows much uneasiness. We watch them closely, as we find many a good pig can be saved by attention the first day.

"As a rule, we feed them nothing the first day, but give them a warm drink of water with a few handfuls of bran added, and a teaspoonful of soda. Everyone must use judgment, as the condition of the udder will soon tell you what to do.

"Never give cold water to a sow after farrowing. If the litter nurses well and then sleep, let them alone-they are putting on fat; but if they are uneasy and keep tugging away at the sow and their hair commences to stand up, look out, for there is trouble ahead. We find the best feed for sows the first week or ten days is whole oats and water with the chill taken off. After that we gradually work in a little thin slop, and have very little trouble about scours with this feed. We keep a sharp lookout for thumps, as that takes away many a good pig. Each sow is turned out for a couple of hours for exercise after the second day of farrowing.

"As soon as the pigs are strong enough to move around we open the little holes leading to the alley in the farrowing house. We save our newspapers through the fall and winter, and every day after the pigs are big enough to get around we unfold papers and throw them in the alley. It is not long until every pig is out in the alley tearing up the papers. It will make you smile to lay on a couch and see 75 to 100 little porkers tearing up papers and fighting among themselves; it beats driving them with a whip, and is the only cure for thumps without work on the breeder's side.

"After pigs are three weeks old they will start to eat-we do not encourage them to eat too soon, as we found out that scours and a lot of little pig ailments are due to the little fellows being started out too early. While feeding them strong early, they will look better and be bigger at a certain age 
than those going out in pasture, but the others will be of stronger bone and bigger frame, expand their stomachs on the clover and grasses, and when six months old will be larger and show more ruggedness than those crowded along too early.

"As a rule, we let our sows wean their pigs themselves, unless we want sows for fall breeding. By the time pigs leave their mothers the sows dry up. We shut the pigs up for twelve hours and then give them three-fourths to one ounce of Santonin to 100 head of pigs. We feed these in medium thick slop, have plenty of trough room, so each pig gets its share. Feed this in the morning; at noon give each pig one teaspoonful of epsom salts in slop. In the evening we water them, but give no feed; the next day we repeat the dose of Santonin, also the salts. If your pigs have any worms you will notice them the second or third day if you are up before the chickens.

"After this operation they get the run of a large pasture of alfalfa and red clover with ground oats and wheat for slop, some dry oats for a change, and also some corn. Enough of this feed is fed to grow them good, but not enough to keep them laying in the yard from one meal to the other. We like to see our hogs after they are fed in the morning go out in pasture and stay there until the sun gets too hot in the summer; then they start out again by $4 \mathrm{p}$. $\mathrm{m}$. and fill up on grass before evening feed.

"They have the run to the charcoal, ashes and salts. Crude oil is used for vermin if any show up. Our yards and houses are kept clean and sanitary. Our aim is to raise 100 to 125 spring pigs and 75 fall pigs. By following this system we never have so many together and can keep them in better health and thrift. By having a liking for the hog business, giving close attention to the little details, and using common sense and not trusting to luck alone, we have been very successful in each year raising a good, uniform, growthy lot of pure bred Poland Chinas that the people all want."

\section{My Way of Selecting the Brood Sow}

We give you here the plan of Charles Marker in selecting his sow, a very successful breeder of Poland Chinas and at the present time in charge as Chief Herdsman of the noted show winning herd of J. E. Meharry, Tolono, Ill., and he has won his high rank as a breeder and herdsman by practical work and in doing things. 
"In the selection of the brood sow, judgment, whether good or bad, has a prominent place.

"My ideal brood sow is one that is a show sow, as well as a business sow. By this, I mean a sow that comes out of the show ring bearing her laurels and also produces get that will rank equally with the mother.

"If you will allow me, I will take Louise Harvester as an example. She is a show sow and a brood sow inasmuch as she won first at the state fairs this fall, and she produced two grand champion sows. She produced the grand champion sow at Iowa and Illinois state fairs, litter sisters, sired by Banker's Model.

"Louise Harvester is a very large sow-will weigh over $600 \mathrm{lbs}$.- and is a show sow every inch of her, and her daughter, Lady Willow, the champion at Illinois state fair, 1912, is, I think, the best we ever owned.

"My kind of a brood sow, to start with, has lots of size, and shows plenty of ruggedness, good length and a good high back, but not enough arch to make the hind feet set under her; good heart girth, good deep sides, just as wide on the belly as the back, good wide chest, legs set well on each corner and a good head and ear, but not too much of baby face on her, for it doesn't look well on a large sow. She should have a good coat of hair; not curly, and not necessary to have a satin coat, but a good smooth coat.

"Always pick out a sow that is a good feeder. It takes too long to get a mincer started, and their pigs will be the same way.

"The brood sow should have plenty of range at all times. Don't keep them too fat, but keep them in a thrifty condition. We feed a slop made of equal parts ground corn and oats and shorts or middlings with a little tankage added in winter, but omit the tankage when they have grass to run on.

"Don't baby the brood sow. Have a good warm house for her to sleep in with plenty of dry bedding, and let her get out and hustle and you will get better results when she farrows. We always put our sows to themselves ten days or two weeks before they farrow so they will get accustomed to their pens before they farrow.

"Be kind to your sows at all times and stay with them at farrowing time.

"In regard to breeding gilts, it depends on the way they have been grown. If they have been 
grown good it won't hurt to breed them at ten months old, but don't breed a little undersized gilt at eight or nine months old. Some of the best breeders don't breed a gilt till she is one year old, which is a good method.

"It is needless to mention that a sow needs plenty of fresh drinking water at all times. Keep lice and nits off of her and free from worms."

\section{Winter Temperature for Pigs}

A number of hog raisers who have introduced artificial heat to warm up their farrowing pens have been at a luss to know what temperature would be best to maintain for the benefit of the little pigs.

An experienced breeder who has been used to heated houses, informs us that 60 is about the right heat to maintain, that the little pigs will frisk and run about playfully with this temperature, which prevents all danger of thumps, as the pigs take the exercise as if it was summer time and thus avoid the thumps.

If the house is kept too warm, it lessens the vigor and weakens the pigs, causing them to be too much like hot house plants.

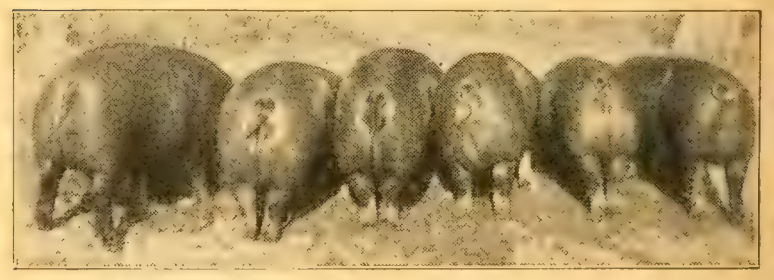

Litter of six, all winners at Illinois State Fair, 1912, in pig class owned by Frank D. Winn, Randolph, Mo.

\section{Individual Sow Houses}

The advantages of a single or individual hog house are their sanitary qualities, aiding in the prevention or outbreak of epidemic and contagious disease, an improvement over where all are housed in one building. We present therefore a house that is generally known as the "Lovejoy style," which has been adopted quite generally by breeders.

"The above cut shows the end and side view of the individual hog house; frame made of 2 by 4 pine, which takes six pieces 2 by 4 , sixteen feet long for the frame. Then enough for the duor and window 
casing. There should be a door at both ends of the house and it should stand facing the south, so the sun can shine in window. No window is needed in opposite end. The matched flooring covering the sides should be dry and well seasoned, so as not to shrink and become open. Building paper should be put on the inside of the frame then boarded on the inside, making it double walled, thus giving four-inch air space between inside and outside wall. This makes a warm house in winter and much cooler in summer. Building paper is also used between the boards on ends and even doors are made the same, with paper between the boards. It is much harder to describe how to build one than it is to build it. We built a number of them at once and did not figure just how much lumber was in each. They cost me some years ago $\$ 14$ apiece, but would cost a little more now, owing to the advance in price of lumber. We had them made by a regular carpenter, doing a well and neat job and are painted with two coats of paint and each with a number on a white shield in gable.

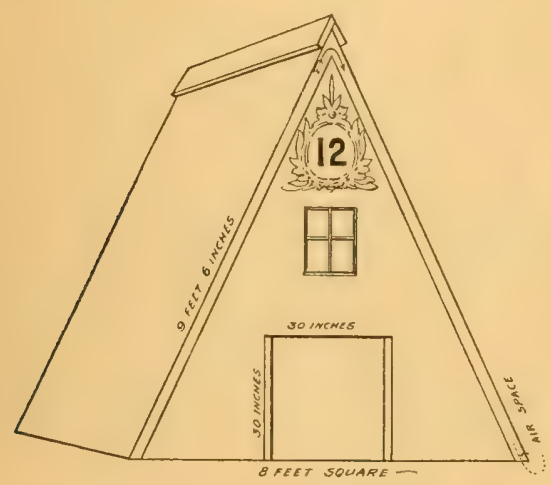

"The top is left two inches apart, as seen in the illustrated view, and is covered by an inverted trough, raised a little, which gives excellent ventilation the whole length of the roof.

"To make the most complete farrowing pen possible you need only to take two pieces of 12 -inch boards eight feet long and nail on both sides on the inside of the door, raising them about nine inches up from the floor and running from one door to the other, forming an alley eight feet long and thirty inches wide for the sow to lie down in, and the little pigs can come out under the boards raised nine inches, as mentioned above, and can have the run of the whole house, and the sow will not lie on them. The sow should be put in this 
alley for three or four days before farrowing and let out a little while each day for exercise and after pigs are farrowed should be kept in for a few days or until the pigs are old enough to take care of themselves and not get overlaid. She can be let out often enough to be freshly bedded.

"The little drawing shows as well as possible how our individual houses are made. It is rather a hard thing to describe so anyone will understand and yet they are simple to make.

"I neglected to say that these houses when the sow and litter of the weaned pigs are in them with doors shut are almost frostproof even in a cold climate, and should one have a sow to farrow in very cold weather he could hang a lantern inside high enough so the sow cannot get to it and he will have as warm a place as he wants for a sow to farrow.

"We allow about one acre of grass lot for each house separated by a woven wire fence. We make the sides of the house about nine feet, so they won't look so squatty in appearance. But they can be made out of 16-foot boards cut in two if desired.

"Hoping this will be understood by your readers and inquirers. A. J. Lovejoy, breeder of Berkshires, Roscoe, IIl.

\section{A Satisfactory Hog House}

The following is a detailed description of the hog house of J. O. James, Braddyville, Ia., a widely known breeder of big type Poland Chinas, who is a successful and experienced breeder, and whose hog house a satisfactory one which others can take advantage of.

It is made of good material and it shows that good workmanship has been exercised. One of the many good features is the hallway which gives ample room for the pigs to take their proper exercise. The windows are so arranged that the sunlight shines in all day. Mr. James has kindly given us full particulars about this structure. Following is what he says:

The size of the building is $24 \times 42 \mathrm{ft}$, height $14 \mathrm{ft}$. with a $3 \times 2$ drop, back side $6 \mathrm{ft}$. to eaves, front side, $7 \mathrm{ft}$. Bill of lumber as follows: 1,000 ft. drop siding, $1,100 \mathrm{ft}$. of roofing, sheeting, $300 \mathrm{ft}$. B. \& MI. for doors, $775 \mathrm{ft}$. of shiplap for lining, $960 \mathrm{ft}$. of rough lumber for floor and partitions, 9-2 M shingles, 300 lin. ft. 1x4s, 2's corner boards and 
window frames, 28 barn sash, 10x14-t ft. lin.; 16 pieces $2 \times 6,18 \mathrm{ft}$; 24 pieces $2 \times 6,16 \mathrm{ft}$; 4 pieces $2 \times 4$, $12 \mathrm{ft}$; 22 pieces $2 \times 4,20 \mathrm{ft}$; 13 pieces $2 \times 4,10 \mathrm{ft}$; 31 pieces $2 \times 4,12 \mathrm{ft}$; 24 pieces $2 \times 4,18 \mathrm{ft}$; 8 pieces $4 \mathrm{x} 4,14 \mathrm{ft}$; 8 pieces $4 \times 4,10 \mathrm{ft}$; $1-2 \times 8,18 \mathrm{ft}$; $2-2 \times 8$, $12 \mathrm{ft}$.

The estimate cost, as building stands, is $\$ 475$.

The first thing one should do in building a house of this kind is to select a place where the ground is dry and drains well, so they can have a lot that will dry early in the spring. You can turn the little pigs out then much earlier than if the house were located where the ground was low and wet.

You should take a team and grade a place at least ten feet wider and longer than that you expect to build the building, then put your foundation on whatever kind you want to use and if the foundation comes above a grade line fill it up with sand and gravel or if this is not convenient fill it in with dirt, then your floor will set right on the ground and there will be no weather or wind to get under the floor. The inside of the house is arranged for 13 sows or can be used for 14 by leaving out the feed bin; but it is very important to have a place to keep the feed. The stalls are $6 \times 8$, ten partitions are made solid, 36 inches high being made so that they can be set in or taken out as one likes. The front of the pen is the same height with a $2 \times 4$ nailed flat ways as seen in the picture. This makes it much stronger and better.

About getting in and out of the pens, the doors are made $24 \times 32$ and are made to slide up and down with a bolt through the top. By having them made this way they can be raised so as to allow the little pigs to come out in the hallway whenever they want to. The hallway is 8 feet wide. This is divided into five stalls, the one in the center is for the stove and the two at each end can be used for sows in case of emergency. The partitions for the hall are made of $1 \times 4$ boards and made in swinging gates so they can be easily taken down. You will find this $8 \mathrm{ft}$. hallway the most convenient part of the house.

The inside of the house is lined with shiplap and sawdust packed between it and the outside wall. We first built the house with just a single wall, but in severe cold weather we found that of a morning that the wall and roof would be covered with a thick coat of frost; as this would melt it would make the house very damp, so we decided 
to line it as above stated and found it a big improvement; as there is never any frost on the walls now, no matter how cold the weather is, and it is much easier to keep an even temperature than with just a single wall.

Again speaking of the farrowing pens, we have fenders on each side and back of the pens, set about 8 inches from the floor, a $2 \times 6$ is plenty heavy enough for this. Some think a pen $6 \times 8$ isn't large enough for 700 and 800 pound sows. We have few of those kind of sows and have had quite a lot of experience with them farrowing in these sized

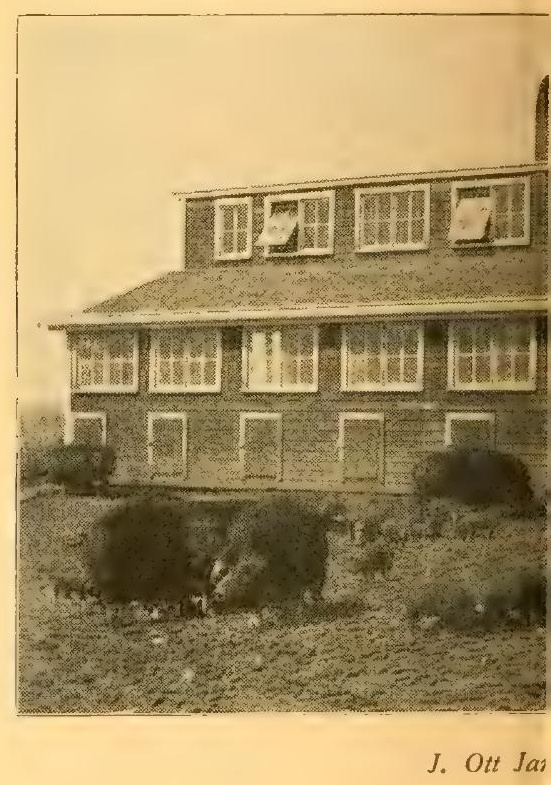

pens. I have also taken out one partition, thus giving a sow a $12 \times 8 \mathrm{ft}$. pen, and could not see where there was anything gained by so doing; as I have found that the worst damage that these extra large sows do to their litters is in getting up and down when they are farrowing and for the first three to five days after farrowing by stepping on the pigs. As many sows do not have a flow of milk to satisfy the pigs for a day or two, the pigs hang on to the teats when the sow is up and in this way get stepped on. I have found the best way to handle these extra large sows is 
to fix the pen so they can't turn around and step on the pigs. This can be easily done by taking two pieces of $2 \times 4$ about 26 or 28 inches and spike them to the back wall 30 inches apart and also spike two the same length and distance apart at the front end of the pen, then nail two six inch fence boards on each side, putting the bottom one about 10 inches from the floor, then nail a board across the two bottom boards about 12 inches from the back wall to keep her from backing up against the back wall. The space gives a sow that will weigh 800 lbs. room enough to get up and down easily and

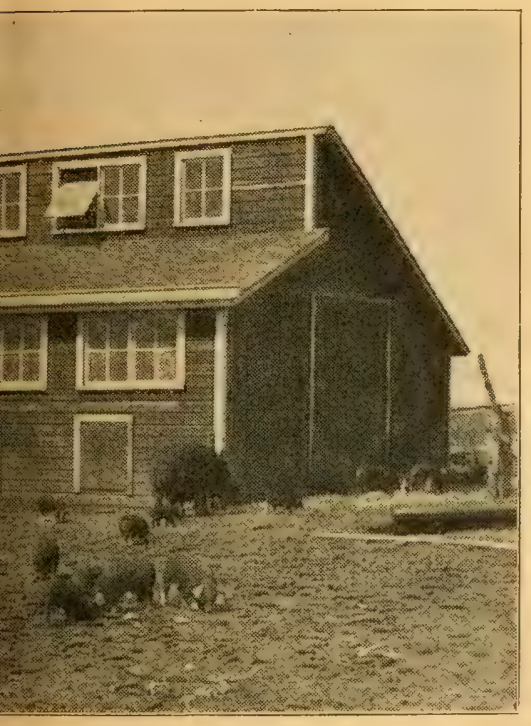

log house

she can lay over flat on either side and she can not flop down quick and catch the pigs, as these boards on each side prevent her from daing this act. It gives plenty of room on each side to get in and clean out the pen and for the pigs to lay in perfect safety, as the old sow can not lay over on them or get up and turn around and step on the best pig she has and kill it.

I would be very glad to have you come and view the hog house yourself, as we have found it to be A number 1 in saving pigs. 


\section{Selecting and Care of Brood Sow}

The following article is from Williams Bros., Villisca, Iowa, breeders of big type Poland Chinas with quality, who have made a marked success of their business and whose advice, counsel and experience must be valuable to every man raising hogs.

"One of the first things we consider in selecting a brood sow is her breeding.

"To the breeder of pure bred hogs this means pedigree and to the producer of hogs to supply the pork market it means practically the same, for every man engaged in rasing hogs should have some system of marking his litters; then by observing his brood sows carefully he can choose brood sow material from sows that have made good, from sows that have produced good sized litters and then have been good careful mothers and good sucklers.

"These are tendencies that are quite likely to be transmitted to the daughters and they are qualities that are absolutely essential if the sow is to prove profitable in the farrowing pen. There is considerable difference from the standpoint of profit, between the sow that raises eight or more pigs and one that raises three or four. These are things that are impossible to determine by looking at the sow, hence the necessity of choosing good sows from good litters and of having a system by which you may know that you are getting them from the right kind of a family.

"We imagine that the lack of a system of marking litters is largely responsible for many farmers raising small litters of pigs.

"If a sow produces only three pigs the chances are she will push them faster than the one raising from seven to nine and they are still ahead when the time comes for selecting the brood sows. Without any system to go by, the man picks the best looking ones and is quite likely to get them from small litters. In a few generations he has a strain of logs that don't produce more than half enough pigs. If, on the other hand, they had picked their brood sows from large litters they could fix this characteristic as well.

"Another thing to consider is individuality and this is as important, perhaps, as breeding. There are a number of different qualities that go to make up individuality. We first, unconsciously observe that indefinable something which we will call character. We say a sow has a broody or motherly look. 
This is in contrast to the sow that is irritable or nervous. We determine these qualities largely by observing her movements for a little time.

"The ideal brood sow should conform closely to the type we are endeavoring to breed, for as "like tends to produce like," we must have a sow that is an easy feeder if we are to produce pigs that are good feeders. We pick a sow that is broad between the eyes, short face and a short neck. She must be a good roomy sow, that is, one with plenty of length and depth, with a good strong back, slightly arched, good spring of rib, one that carries her width evenly from end to end. We would seriously object to a sow that is deficient in heart girth, as it indicates a weakness of constitution and a lack of heart and lung room. We can readily see the necessity of having plenty of room for the organs of circulation and respiration when we consider that the sow must breathe for these unborn young as well as supply them with nourishment for their growth through the blood.

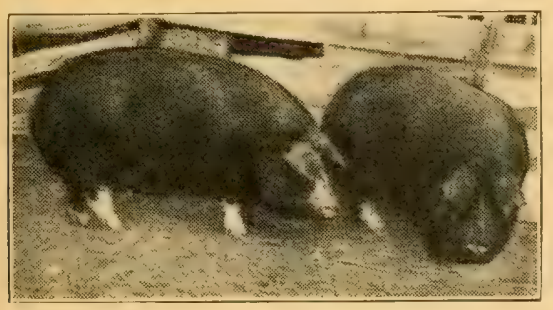

"When it comes to feet and legs we are especially particular. We want a sow with a good strong bone, or, might we say, a heavy bone. However, the number of inches of tape line it takes to go around the hog's leg doesn't determine whether the hog has a good bone or not. There is such a thing as quality of bone. Consequently we demand a sow with a good sized, clean, flinty bone. We want our sow to have short, straight pasterns and stand up straight on her feet. The kind of a pastern and foot the hog has, has more to do with him carrying his weight properly than the size of the bone. When we can get a sow with a large bone of the right quality and texture so much the better, but the brood sow must be able to get out and carry herself around in good shape while carrying her litter, as exercise is a ve.y important factor in her producing good, strong litters.

"Now as we have been writing about the brood sow and have confined our remarks to her alone 
we want to say we think the selection of the brood sow almost as important as the selection of a sire. Now we don't want to be thought of as not advocating care in selecting a sire, but we don't think, as we had a breeder remark to us not long since, that the boar is nine-tenths of the herd. We immediately took issue with him, but remarked that we were afraid it was true in some cases, but it should not be.

"The care given the brood sow from the time she is bred until she farrows, and the sow and litter from then until weaning time, largely determines the profits derived from the hog business on the farm.

"In order to get the best results from our sows we begin to give them special care a month before we want to breed them.

"The matter of fecundity in the sow is determined first by heredity, which we consider in choosing the brood sow, and in the second place by the care she is given previous to being bred. The sow should be in the very best condition at the time she is bred, consequently about a month before breeding time we increase the ration (which should be a well-balanced ration) to the aged sow as well as the younger stuff which should be kept growing all the time.

"In this way we bring them up to breeding time gaining in flesh. We have demonstrated to our entire satisfaction, that by following this plan we can get larger litters than by not giving the sows any special care before breeding.

"In our herd last year we had 36 sows farrow 366 pigs. These prolific qualities have been cultivated by giving attention to heredity and care previous to breeding.

"After the sow is bred until she farrows, she should be given a ration rich in protein and bone making material. The unborn pigs must receive all the nourishment to make them grow through the dam, and when we consider that the pig at the time of birth is composed almost entirely of bone muscle with very little fat, we can readily see the necessity of feeding the sows a ration that will produce this bone and muscle. We like part of this ration to be quite bulky.

"Some of the feeds that might be used to sunplement the corn in the ration are bran, shorts, oats, tankage, oil meal, alfalfa in various forms or bright clover hay.

"The best feed we have ever used has been chopped alfalfa hay in generous quantities mixed 
with the other feeds and after being wet good put in their troughs. This feed is bulky, cooling and keeps the sows in fine condition. They milk good and don't scour the pigs as when fed lots of shorts or other concentrated feeds, and being bulky the old sow is full and goes to bed contented.

"The reason we dwell on alfalfa as a part of the ration is because it is a bulky feed that is very rich in protein, and where we can raise it on the farm, as we believe we can, on almost any welldrained corn land, we can thereby materially cheapen the ration.

"Where one doesn't have alfalfa, second crop clover or even first cutting of cut at the right time and properly cured, may be used to take the place of alfalfa in the brood sow's ration. Another thing of prime importance is the matter of exercise. The sow must be forced to take exercise every day if she will not take it voluntarily. Aged sows especially, if well fed, are the most lazy animals on the farm, hence the necessity of forcing them to take exercise. One way of getting them to take exercise is to feed part of their feed at least as far from their sleeping quarters as possible.

"The sleeping quarters should be dry, roomy and well bedded in order to prevent piling up in cold weather.

"Of course, all breeders, and we take for granted, all farmers, who are raising hogs in earnest, keep a list of their sows and when they are bred, so they know when the sow is due to farrow.

"About a week before the sow farrows we shut her away in the pen where she will farrow her pigs. Always take time then to get acquainted with the sow. Get into the pen and handle her. She will soon learn that you are her friend and mean no harm. By the time she farrows her litter she will be quite tame and easily cared for at that time. After shutting her up we decrease the amount of feed, shutting off altogether on corn and giving a cooling bulky ration like bran or oats. It is very necessary at this time to guard against constipation, hence the value of this kind of ration.

"When the sow farrows we always have some one there to look after her whether that time is midnight or noon. If the weather is cold, as soon as the pigs come put them in a box, and if necessary have some kind of artificial heat to keep them warm. In any event, look after the pigs until the sow is through farrowing, when they may be put with the sow and allowed to nurse. When they have become 
thoroughly warm and well filled with milk their chance of getting along is good. This period and a few days following is the most critical time in the care of the brood sow.

"Have her in good comfortable quarters with a good, clean, dry bed. we say first, don't give her anything to eat for twenty-four hours, but give her a drink of good, clear water. Then begin by only giving her a real small amount of feed, such as shorts, ground oats or barley and chopped alfalfa. We never give any corn before three days after farrowing, and sometimes not that soon and then very small amounts.

"There are great numbers of pigs lost each year from neglecting to feed the sow properly the first week or ten days of the pigs' lives. Do not be in a hurry to crowd these pigs, for they don't need as much the first week of their lives as many imagine. A little too much rich feed the first few days is very apt to give the pigs the scours, and if so you have given the pigs a setback that very many of them never get over, so feed sparingly the first week or ten days and increase it gradually as the litter becomes able to take more.

"It is a great drain on the sow to suckle a large litter of pigs, hence the necessity of feeding plenty of good, rich food, giving a ration that is conducive to a large flow of milk.

"Right here we want to say that exercise is absolutely essential for the litter especially; of course the pigs that are farrowed when it is warm take care of themselves, while those that come in colder weather must be forced to take exercise, or they become fat and take the thumps from which there is no cure, at least we have never found one that was one-tenth part as good as prevention.

"We have had a number of men tell us that their pigs just laying in the nest, fat and doing fine, as they thought, just dropped off one at a time with thumps; so give them exercise, whether they want it or not, and avoid the thumps and this consequent loss.

"Now as soon as these pigs get well started and get to eating some out of the trough with the mother, make a place for the pigs to go in where the sows cannot, and put some feed there for the pigs. They soon learn where it is and will be on hand for it at feeding time. They thus supplement the milk, and as they get ten to twelve weeks old they can be weaned and go right along and never miss the sow. 
"If the pigs are farrowed within a short space of time they may be all handled together this way, but if the farrowing season extends over a considerable length of time they must be separated, for "pigs is pigs," and the larger will rob the smaller ones, and after all are weaned the big ones crowd the smaller ones out so they cannot get their share of feed and so do not make the gain they should.

"The more lots and pastures one can have in which to keep the different ages and sizes, the more satisfactory and profitable the hog raising will become.

"We have mentioned a few of the common mistakes and suggested remedies and just want to mention one more thing, that we all have to contend with more or less, and if to any extent it proves a serious menace to the profitable production of pork if not attended to at the right time, it is worms in the pigs. All pigs seem to be affected more or less, and we never know how badly they may get, so, as with other things, the best thing is to expect them and feed something to prevent. There are a number of worm remedies on the market, and each endorsed by successful swine raisers, so it is left to you to choose. which one you will use; but use something and begin in time, before you wean the pigs, and whatever one you use follow the directions for feeding and you may save yourself a lot of grief.

"So just keep the pig thrifty, free from all these parasites, and keep him growing all the time, and do it every year and your hog business will be a paying one."

\section{Selection and Care of Brood Sow}

The ability and success of Lloyd Mugg, Kokomo, Ind., as a hog man of national reputation is well known, having spent nearly half a century as a breeder, showman and judge, and placing the ribbons at some of the most important state and greatest fairs of the country. $\mathrm{He}$ is justly considered one of the Supreme Court judges of swine. The benefit of his knowledge and experience in selecting and caring for the brood sow is worth good money to any breeder; even the best breeders acknowledge that there are none of them who cannot learn every year of their lives something of advantage from the experience and knowledge of others. Here is Mugg's plan:

"I would select a young gilt or sow out of a good brood sow and from a big litter. The gilt should be of good color, coat and good growth. She 
should have a good, broad head and face, nice ears of medium size, good neck and jowl, broad, straight back and loin, medium in length of back, so as not to swag down. I want good, deep hams and shoulders, the hams well let down on hocks. A good under loin, even, wide belly, and a good number of teats, not less than ten good ones or more. Good, large chest, strong, stout bone, short legs, short in joints, good feet and legs set well under the body, straight and wide apart.

"This gilt should be taken good care of from time of selection until matured and grown on good feed. I use bran and shorts mixed about half and half in water, slop or milk. I often use one-third corn and two-thirds oats ground fine, fed in slop. I feed a small amount of corn also. The gilt should have a good run of blue grass or clover as much as possible to give her plenty of exercise. I keep this sow pig growing fast and in good flesh until eight or nine months old, providing she was an early spring gilt, she would be ready to breed to a good boar about November 1st. I feed and care for the sow in the same way as mentioned heretofore. She should have a good, dry sleeping house, kept clean and well disinfected. After breeding her I would not let her run and sleep with too many other sows or pile up with hogs. She must have plenty of exercise through winter. Two weeks previous to farrowing I would put her by herself in a good house in cold weather. I use a house where I have a stove. This house is so it can be ventilated or shut up if necessary. Adjoining the house I have a lot so the sow can be let out to exercise. Upon putting the sow into this house I stop feeding her corn and feed her only slop stuff.

"When the sow farrows, I am with her to see that the pigs are not chilled. I take the little pigs' teeth off by the use of a small pair of nippers to prevent their fighting over the teats and biting the sow. This biting often causes the sow to jump up and drop down on them, and there is danger of injuring or killing a pig.

"I then leave the sow for eight or ten hours and then I give her a drink of water with some bran and shorts mixed thin. I also throw in the remains kept from my butchering, in rendering the lard, called cracklings. This keeps the sow's bowels in good condition, and as the pigs get older I increase in the feed of slop in quantity, making it richer with the shorts, and when the pigs are ten or fourteen days old I commence feeding the sow a little corn twice a day, but not too heavy on corn. 
"When the pigs are old enough to go out with the sow I let them run out, providing the weather is fit. I want them to have the exercise. If the weather is too bad I make them take exercise in the house by getting in with them and running them around while the sow is in the out lot. When the pigs are a month old I begin feeding the little pigs by themselves and I increase the feed for the sow as I think she needs it and increase the feed to the pigs. I use milk or kitchen slop to mix pigs' feed when I have it. Also use shelled corn and cracklings when I can get them. They are good feed for the sow and pigs. The sow and litter should have plenty of exercise and be kept in good dry beds. Disinfectants should always be used. When the litter is about three months old I wean them, as they have learned to eat and will grow nicely from this time on. If I want to keep the sow as a brood sow I turn her out on pasture of good, green food. with a small amount of ear corn. Then she will be in good condition for breeding again. I have said nothing about oil meal, condition powders, or alfalfa meal, as I do not use them, I always want to use what I grow on the farm so as to be able to sell as cheap as possible to my customers and hold my trade and give satisfaction."

\section{Non-Breeding Sow Treatment}

This remedy is one that has been used with unfailing success for fifty years by a veteran breeder who has the utmost faith in it.

A breader will sometimes have a sow, that after repeated trials fails to breed and if the sow is one of extra value, this failure is quite a loss to him and he is anxious for information of an easy way to treat her to insure her to breed.

A sow thus affected is suffering from a disease, which is sometimes called by breeders "Whites," because of the discharge of this color from her. His treatment for a sow in this condition is to use "Hemp Seed." This can usually be secured at any drug store, and this party has never failed in 50 years in getting a sow to breed that was treated in this manner, and his reputation for success became so well known on this treatment, that sows have been sent to him that liad failed to breed for over two years, and inside of two months he has them proven with pig and raise good litters.

The treatment is one-fourth of a pint of hemp seed twice a day in the morning and evening, fed in a slop made of bran and shorts. This can be followed for a week or two weeks if necessary until it proves a success. Sometimes it takes more 
than at other times, depending to some extent on how long the sow has been in this diseased condition. While this is a home remedy it is simple, cheap and easily administered.

\section{Treatment for Aborting Sows}

I will give you some actual experience with sows aborting. I had trouble of this kind in my herd about two years ago, and experienced considerable difficulty before it was completely eliminated. My experience would indicate that all sows and gilts that show the least indication of a light discharge should be put in a lot by themselves and their pens be kept thoroly disinfected; then as fast as these gilts or sows come in heat, treat them with an iodine wash; using two ounces of iodine to 2 quarts of warm water. The sow should be put in a breeding crate and a rubber tube syringe used, holding the wash above the sow as far as the rubber hose will permit, which is usually about three feet. Use the largest size hard rubber tip that goes with the syringe (a little vaseline should be used on the rubber tip). The parts should be thoroly cleansed by the iodine wash. Never treat the sow unless she is in heat, and repeat the treatment the second time in heat if the case is bad, and she shows any indication of the disease, or the parts show an unhealthy inflamed condition.

Do not breed the sows for twenty-one days after she has been treated, and then not, unless she is in good condition. As soon as the sows have been treated, place in a lot away from the other hogs and keep the pen thoroughly disinfected. If any are not completely cured after the second treatment they should be taken from the herd. The disease seems to be very difficult to control in a very large herd, but not so difficult in a small herd, as you know the disease is contagious. It was caused in my herd by feeding smutty rye and had quite a start before I was aware what was causing the trouble; the discharge was at first very slight, and I experienced considerable trouble getting some of the sows with pig. This condition gradually grew worse, until it developed into abortion; I then started to treat the sows and reduce the herd and soon had the herd entirely free from the disease. Never treat a sow when she is with pig, as it will cause her to lose her pigs. If she shows symptoms of the disease, put her by herself until she has her pigs, then treat her the first time she comes in heat. The treatment in no ways injures the sow and once cured will stay cured. My sows that were cured had large strong litters and I saw no bad effects in the pigs; the disease apparently being a local one.-J. D. Collins. 


\section{Easy Farrow}

One of the breeder's duties is to prepare the sow for an easy natural farrow. The sow that is constipated at the time that she is due to farrow is in had condition and this should be prevented. Constipation calses difficult farrowing and labor. It is also the beginning of a fever that adds to the burden of the sow and causes her milk to be harmful to her coming litter. There is always every year more or less trouble on some farms, especially with young sows farrowing. The sows should always have had sufficient exercise, daily if possible, from breeding time up to farrowing time and received feed of a laxative character, preventing constipation and just giving them free natural voidings. Nothing is much better for a week before farrowing at any time and especially if there is any show of constipation to give them in their feed a double handful of oil cake meal. Also to assist the sow into the proper condition she should be fed some cracklings as we have mentioned elsewhere.

In the event that the sow is in bad condition of constipation she should be given a mild physic with a good dose of Epsom salts, if she is not relieved by the linseed oil cake; care should be taken not to produce scours and all changes of feed should be gradual. It is presumed that the sow has had access to wood ashes, charcoal and some lime and if there is any show of weakness in the hindquarters a little phosphate of lime is a help.

At the time she is due to farrow she should be carefully watched and attended to, so that the pigs can be taken care of as they come, dried and put in a warm box in which a warm brick wrapped up in gunnysacks will keep the pigs in a comfortable condition until they are put to her to suck and get their first nourishment. By doing this you will protect the pigs, save them and prevent the sow from lying on them, by putting them back in the basket after they have had their first fill.

Feed lightly for three days before the sow is due to farrow and if she is in good condition there should be no trouble to her in farrowing. After farrowing she should not be fed anything but warm water, with a little bran, the first 24 hours and but very light feed for three davs after farrowing so that the milk will not be forced, as the pigs need but little and an over-supply left in the udder causes fever and deranges the little pigs' 
stomachs, bringing on scours. This treatment will usually give an easy farrow; have had no trouble with sows farrowing in five years by treating in this way is the report of an Illinois breeder.

\section{Brood Sow Pointers}

Have your brood sows take daily exercise each day, unless the weather is too stormy. It is a necessity, next to feed, for the benefit of the coming litter.

The brood sow does not need fattening feed, but feed to build muscle and bone. She should be in good flesh, strong and vigorous with only enough corn given to keep up the heat in cold weather.

The brood sow should be fed a laxative feed to keep the bowels in good condition. Oil cake meal is one of the best aids for this purpose, a handful for each sow in the slop will usually keep the bowels in good order.

Free access to a box of charcoal, lime, wood ashes, all of which is moderately salted, will furnish mineral matter, which is needed by the brood sow for maintenance of the sow's bones and the growing of the bones of the litters.

Be careful that your sows or pigs, in their sleeping quarters, are not subject to cold air draughts upon them, as colds are often taken this way and sometimes runs into pneumonia. Ventilation is all right and needed for health's support.

Do not feed your brood sows after breeding them any rye, either whole grain or ground, nor rye bran or middlings. Rye carries more ergot than any other grain. Ergot eaten by the sow is sure to produce abortion. This ergot is apparently a blighted black hard substance growing on the head of the rye.

Sows that have been bred for Spring litters every season by some feeders in some section (but seldom the second time) are injured, and the litter virtually lost by abortion or weaklings if they carry till farrowed, because of feeding a ration of too high a percentage of protein, being an unbalanced ration and causing more serious losses than from too large a percent of carbohydrates. Take the benefit of the other fellow's costly experience and beware. 


\section{Experience in Selecting and Handling Brood Sow}

Chas. E. Keller, Newark. Ohio, has won his laurels as an experienced, successful breeder and developer of swine and proved it with the goods. His success at the World's Fair in St. Louis in capturing the championship on sows, whose picture is given herein, established his record as a famous breeder and he has been making good ever since.

We are pleased to submit to the readers of this book from his hand, his ideals, plans and methods of selecting and caring for the brood sow.

"I will start this subject by selecting a gilt of early spring farrow that has had good care and is well developed. My first consideration in choosing this gilt is to know she is from a prolific family, but some times we get small litters from sows whose dams have proven themselves prolific mothers, which cannot be accounted for. These are exceptions.

"Experience has taught me that a sow selected from such a litter is as prolific as the family selected from.

"Next, the individuality of the sow is looked after. She should be of ample size that would at mature age weigh around $600 \mathrm{lbs}$. or over with good quality. The word quality as I have used it, pertains to all of the different qualifications of the sow, show quality, feeding quality and killing quality. She must have good length, strong arched back with a well sprung rib, deep sides with flank well dropped and a straight under line. Her hams should be deep and wide and should carry the width well down; the neck should be short with a full crest, short nose and wide head, with face slightly dished, a natural sized thin ear, breaking over one-third to one-half from the points; set wide on head, with points of ears standing as wide apart as possible. She should have a medium sized jowl and a full wide chest with legs set well apart, with a good sized bone of finty quality. There should be as much consideration for the quality of the bone as for its size. The legs should be short and slightly tapered with short pastern joints, straight in hock joints as possible. Good strong straight feet, standing up on toes. She should have a thin straight, soft black coat of hair which denotes a thin skin and mellow finish, with easy feeding qualities and free from creases. Feet, tail and nose should be slightly tipped with white, which is merely a condition of fancy. 
"This gilt should be bred to farrow the last of March or first of April so she may pick a little green grass which will stimulate the milk flow. The gilt with her first litter never furnishes the nourishment that is produced by the aged sow.

"After she is bred give her access to good range that she may take plenty of exercise. A sow that fails to be exercised is liable to become out of condition and bring a weak puny litter. She should have a dry, warm sleeping house kept in a sanitary condition and furnished at all times with good bedding so that they will not pile up during the extremely cold weather.

"Experience has taught me they should not be crowded in their sleeping quarters, nor should too many be permitted to sleep together during the cold winter season.

"I feed my brood sows a limited amount of slop composed of bran shorts and oil meal. I would advise slopping once a day and feed oats and corn once a day. If you see the sow is taking on too much flesh cut down the corn ration and feed more oats. The feeder must use his own judgment in this matter, the sow should be kept in strong flesh but not to get fat, a sow in high flesh will farrow a good strong litter but often fails to furnish the proper amount of nourishment that the young require to make a thrifty and rapid growth.

About one week before time to farrow I take her to the farrowing house which contains 6 pens $7 \times 7$ feet and a four foot aisle in center with a stove at one end of the aisle. Each pen is protected with a rail fender $2 \times 4$ placed 10 inches from the walls and the same distance from the floor to prevent sow lying on pigs. Each farrowing pen is provided with a lot for exercise. When the sow is taken in the house I cut out the grain ration and just feed bran slop with a little oil meal added. When the sow farrows I am with her, for some sows become nervous and uneasy at such times. Constantly getting up and down, rolling from one side to the other is likely to kill a number of the pigs while farrowing. If it is cold weather have a fire in the house to prevent the pigs from piling. If the sow is uneasy place pigs in a basket before the fire as fast as they come, if she is quiet keep them in the nest and get them to nursing as soon as possible. As soon as she is through farrowing, I cut their tusk teeth off close to the gums with a small pair of nippers which prevents them biting the sow if they fight over the teats. This biting causes the sow to become uneasy and injure her pigs by getting up and down. Keep 
the sow quiet until she shows signs of wanting somcthing, then offer her a drink of water which is usually from six to ten hours after farrowing. The second day I give her a very thin bran slop with a little oil meal. If her udder seems hard and caked place in the slop one tablespoonful of Glaubers Salts and one teaspoonful of Saltpeter once a day, continue feeding bran slop and oil meal but sparingly as long as there is fever in the udder. If the feed is increased it will induce a greater flow of milk than the little ones can consume and consequently the udder becomes caked and the pigs starve and die. After the first week I feed some whole oats with the slop and when the pigs are four weeks old I begin using shorts in the slop, two parts bran and one part shorts, also some corn and a little less oats. The amount they should be fed must be governed by size of sow and the amount of exercise she is permitted to take. If she farrows in cold weather and is confined to the farrowing house she should be fed more sparingly than if she were roaming over the fields. The most trouble with the little pigs comes from indigestion through the mother. If her digestion is all right there will be no scours in the litter.

"If it is too cold to turn the little pigs out, I let the sow out, for exercise and while out I clean and disinfect the nest and add dry bedding. This prompts the little pigs to take part in the work for they like the plan after their nest is renovated.

"Some time a litter gets fat and lay in the nest, when this is discovered, they are taken out several times every day and placed in the aisle of the hog house, which causes them to fret and worry trying to get back to the sow, and in a short time they will become active and exercise in their pens, otherwise thumps will be the result.

"As soon as the pigs are inclined to eat, prepare a place away from the sow to feed them. A nice clean corn meal and a small quantity of oil meal scalded with boiling water, and thinned with milk direct from the cow is the best and cheapest feed I can prepare for them. When older I feed them some shelled corn. When ten weeks to three months of age, I wean them and turn the young sow on a good range of grass and feed her well all summer, that she may make a good growth and be in strong condition to breed for a litter. I never allow a gilt to raise but one litter the first year. Do not turn this young sow with old ones to chew her ears off and whip her to death, for she will not thrive under such treatment. 
"Miss Fairbanks was the first prize gilt and junior reserved champion and one of the Lena Perfection litter that won 8 prizes at the World's Fair St. Louis in 1904. In her yearling form she was grand champion sow at Ohio State Fair and one month later she

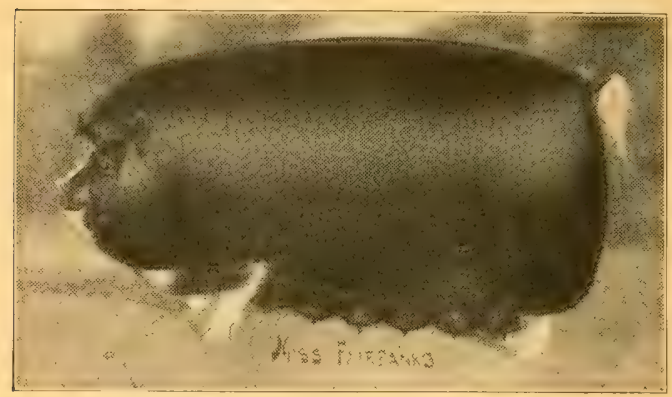

Miss Fairbanks, 700 lb. brood sow

was grand champion at the Illinois State Fair where she met and defeated the grand champion of Iowa, Missouri and Indiana. She row is in her 9th year of age and last spring she farrowed 7 strong pigs and looks to be good for several more years.

\section{A Successful Breeder's Methods}

The man who has made a success of his business, is always entitled to the attention of his fellow men engaged or interested in the same line. He is able to give them advice and instruction of just how he proceeded to reach success in his business. Anyone searching for information to enable them to attain success, can thus profit by the instruction they get from him.

You will discover by investigation that a good portion of the accomplishment of a herd of hogs is caused by the skill of the feeder, no matter how excellent the hogs themselves are, the feeder's work is an important part to their success.

Judged by results entitles R. M. Cassell, La Harpe, III., a place in the front rank of the best feeders and developers in the United States. We present below from his own hand a statement of his ideals and how to select them, and his method of handling, feeding and caring for them. As a breeder of Big Type Poland-Chinas, he has made a reputation second to none.

"The boar is called half the herd; the sow therefore, must be the other half. In my experience the results from different sows have, of course, been varied. The sow of my choice has not always been 
the best producer. There are sows of ideal proportions, that are failures as breeders, in that they do not reproduce true to their form. I have found a safe rule to go by; that is, that LIKE PRODUCES LIKE, more so in the hog family than in any other stock. If we select our sows when young, paying particular attention to size, quality and the size of the litter she is from, we may be reasonably sure, by properly feeding, to have a profitable brood sow.

"In selecting the future brood sow I try to get one with great length, she must be wide from end to end, the back well arched and above all avoid that droop behind the shoulder, well sprung rib and the head short and wide and a heavy jowl. The top and bottom lines should be near the same distance apart

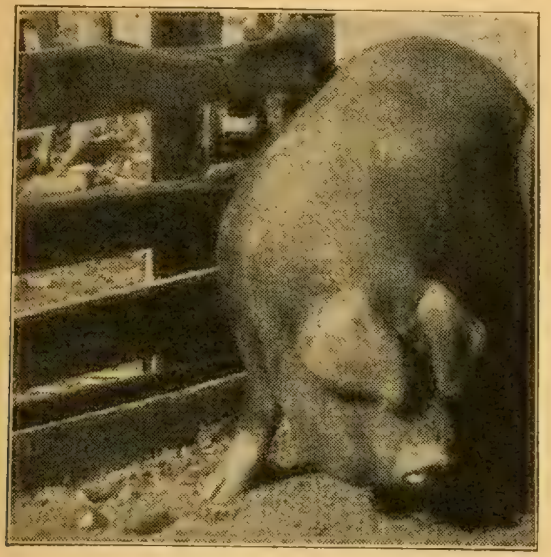

A 700 brood sow in my herd

the entire length. I avoid the small boned gilt, also the one with bad feet. I like the medium to small drooping ear, but will stand for an ear a little too large if the other points mentioned are all right. It is needless to say that I avoid the swirl.

"The feeding I consider a very important part of the brood sow problem. I like to keep the gilts up in good flesh, that is, I keep them growing and gaining from the time they are bred until farrowing time; now I do not mean that the gilt should be fat; there is a great difference between a gilt that is in good growing condition and one that is fat. A stunted animal, rarely attains the size that one does that is carried along in good condition.

"I seldom breed the gilt to farrow before she is a year old and two months later is better. After farrowing she is fed carefully, watching her litter all the time and increasing her feed to keep her up in flesh as a set back at this time is detrimental to the 
future brood sow. The young sow is kept separate from the older sows, as she requires more feed to keep up her condition and is usually allowed to wean her litter herself. I rarely breed the young sow for a fall litter as I usually have plenty of older sows for that purpose.

"The gilt is given as much of a variety of feed as the farm affords, she has clover hay, oats, some corn and a slop made of shorts, ground oats and wheat or rye and always a large field, preferably clover, to run on. I consider oats one of the most valuable feeds we have; I have fine results using it in the brood sow ration, it seems to balance up the feed in a satisfactory manner without the expense of buying the much advertised foods.

\section{How to Select Feed and Care for Sow}

We give you the plan and method of handling the sow and litter by Geo. W. Sefrit, Lucas, Ia., breeder of Big Type Poland-Chinas who has made a great success in the breeding business as results show. These plans are from his worked out experience thoroughly practical in every particular.

"In giving you my methods of handling the sow and her litter I will start with the sow before breeding. The sow should be from a good family, with good disposition and a good suckler. If she is not a good milker she will not raise good pigs, no difference how good an individual she is. She should be a large roomy sow with a good bone. arched back and straight wide lines, with a smooth coat. Here is presented a picture of one of my best brood sows, Nellie Price, bred by myself and has proved a wonderful good brood sow.

"The sow should farrow a good sized litter; but am not particular about extreme large litters, such as 12 to 14 , my preference is for 8 or 10 as being better.

"Don't get the sow in too high flesh before breeding; but have her in good thrifty shape when bred; then feed her so as to gain a little more flesh from that time on; but don't feed her much corn, feed ground oats, bran, shorts and alfalfa. Be sure and have her take plenty of exercise, this is a necessity for best results. Always use a breeding crate when using a large aged boar. The boar should be fed a balanced ration consisting of corn, ground oats, shorts and milk; but don't get him fat, keep him in a pasture away from the other portion of the herd, give him plenty of exercise and don't overlook the fact that a good herd boar will pay to use always, the extra cost will be a good investment.

"I take the sow away from the herd a week or ten 
days before farrowing time, place her in a small pasture to herself with an individual farrowing house where she will have things quiet and to herself. Make the farrowing pen 7 feet wide and 9 feet long with a window in one end and a door at the other. Have the door facing to the South, if she is a very large aged sow have a door in both ends. The sow can then go in at one end and out of the other and will not be so apt to trample on the little pigs. If the weather is cold, line the house with tar paper and bank it up on the outside, so that no frost will get in. If the weather is very severe hang a large lantern inside or get a carriage foot warmer, either one will keep the house in good shape almost any kind of weather; but be sure and have some ventilation. Just as soon as the weather is fit hang a canvas or gunny sack over the door nailing it at the top of the door and let it hang loose at the bottom. The sow can then go in and out at her pleasure.

"If the sow has been taken care of in the right way, the pigs will be large and strong at farrowing time. Always look after the sow when farrowing and get the little fellows to sucking as soon as possible. If they get chilled take them to the fire and warm them and get them to nursing as soon as you get them warm. This is a good time to mark the litter, also remove the little tusks and be sure and do not pull them out, nor break them; but cut them square off. There are several instruments made for this but none that suit me, so I got a pair of side cutter pliers and sawed six jaws and have only the side cutter left and they are just the right thing.

"I feed the sow lightly the first few days before and after farrowing time, don't feed much corn, feed ground oats and bran, as bran is one of the best feeds there is for sows at farrowing time both before and after. If the sow is fed the proper ration she will seldom eat her pigs, if she should show any inclination to eat them, give her a little tankage and then take a cloth saturated with kerosene and rub over the pigs once a day and she will not be apt to touch them.

"Keep the farrowing pen well cleaned out and disinfected, with good clean straw for bedding, get the pigs to eating as soon as you can, feed them on shorts and milk with some soaked shelled corn. Keep the sow in an individual pasture until the pigs are a month or six weeks old, they then can be taken to larger quarters.

"If the pigs should get the scours it is the fault of the way you have taken care of the sow. The first thing to do is to change feed of sow, feeding her on bran for a day or two and perhaps a good dose of 
salts would be good, then one tablespoonful of sulphur once a day for two days. Keep the pigs and sows out of filth and mud and disinfect the pen; also keep some charcoal where the sow can have access to it.

"I have a large hog house made for sows farrowing, with hall four feet wide and pens $6 \times 8$ arranged so that the windows will let the sunshine in both rows of pens. Some breeders think this is a good way to have sows farrow. I use both kinds but prefer the individual pen for several reasons. I think pigs are more subject to disease in keeping many together and the sows do better when there is nothing to bother them. When several sows are in one hog house and one sow steps on a pig and the pig squeals the rest of the sows in the hog house will jump up and perhaps there will be other pigs

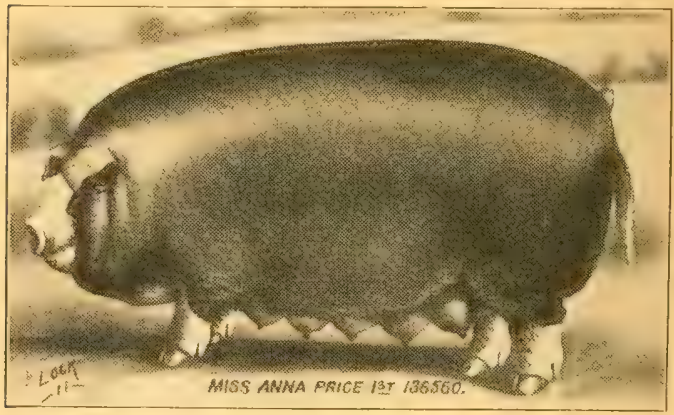

Anna Price 1 st 700 lbs. Poland-China sow with quality, a good suckler, always raises two litters a year.

stepped on. If some of the sows are farrowing it is necessary to keep the hog house too warm for the rest of them that have older pigs.

"If the pigs should get canker sore mouths, make a little solution of corrosive sublimate, one tablespoonful to a half pint of water, take a small syringe and inject it into the small ulcers and be sure to get to bottom of canker. Take a little probe and remove all foreign matter before injecting. Do this once a day for three days and your pigs will be all right; but the pigs will never have canker sores if they have plenty of air and sunshine and are kept in good clean quarters.

"I will also add that I raise but one litter of pigs a year from a gilt; but after the first year I breed them for two litters a year, and find that they do as well, if the sow has proper care. With large sows they get too fat if you only breed them for one litter, and do not do as well as when they are bred to raise two litters a year. 


\section{AVERAGE VALUE FEED STUFFS.}

\begin{tabular}{|c|c|c|c|c|}
\hline \multirow{2}{*}{ NAME OF FEED } & \multirow{2}{*}{ 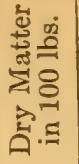 } & \multicolumn{3}{|c|}{$\begin{array}{l}\text { Digestible Nut- } \\
\text { rients in } 100 \mathrm{lbs} .\end{array}$} \\
\hline & & $\begin{array}{l}\text { Crude } \\
\text { Protein }\end{array}$ & $\begin{array}{c}\text { Carbo- } \\
\text { hy- } \\
\text { drates }\end{array}$ & Fat \\
\hline 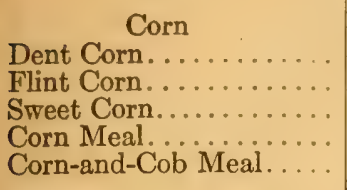 & $\begin{array}{l}\text { Lbs. } \\
89.4 \\
88.7 \\
91.2 \\
85.0 \\
84.9\end{array}$ & $\begin{array}{r}\text { Lbs. } \\
7.8 \\
8.0 \\
8.8 \\
6.7 \\
4.4\end{array}$ & $\begin{array}{l}\text { Lbs. } \\
66.8 \\
66.2 \\
63.7 \\
64.3 \\
60.0\end{array}$ & $\begin{array}{r}\text { Lbs. } \\
4.3 \\
4.3 \\
7.0 \\
3.5 \\
2.9\end{array}$ \\
\hline 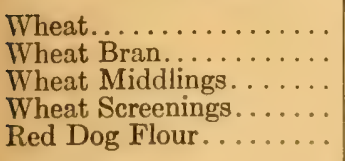 & $\begin{array}{l}89.5 \\
88.1 \\
88.8 \\
88.4 \\
90.1\end{array}$ & $\begin{array}{r}8.8 \\
11.9 \\
13.0 \\
9.6 \\
16.2\end{array}$ & $\begin{array}{l}67.5 \\
42.0 \\
45.7 \\
48.2 \\
57.0\end{array}$ & $\begin{array}{l}1.5 \\
2.5 \\
4.5 \\
1.9 \\
3.4\end{array}$ \\
\hline 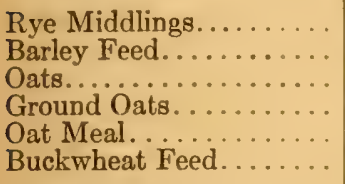 & $\begin{array}{l}88.2 \\
91.1 \\
89.6 \\
88.0 \\
92.1 \\
88.4\end{array}$ & $\begin{array}{l}11.0 \\
11.5 \\
10.7 \\
10.1 \\
11.9 \\
15.6\end{array}$ & $\begin{array}{l}52.9 \\
60.3 \\
50.3 \\
52.5 \\
65.1 \\
38.2\end{array}$ & $\begin{array}{l}2.6 \\
2.9 \\
3.8 \\
3.7 \\
6.7 \\
4.4\end{array}$ \\
\hline 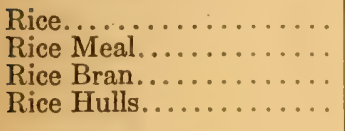 & $\begin{array}{l}87.6 \\
89.8 \\
90.3 \\
91.2\end{array}$ & $\begin{array}{l}6.4 \\
7.4 \\
7.6 \\
0.3\end{array}$ & $\begin{array}{l}79.2 \\
48.3 \\
38.8 \\
19.9\end{array}$ & $\begin{array}{r}0.4 \\
11.9 \\
7.3 \\
0.1\end{array}$ \\
\hline $\begin{array}{l}\text { Canada Field Pea....... } \\
\text { Cowpea................ } \\
\text { Soybean........... }\end{array}$ & $\begin{array}{l}85.0 \\
85.4 \\
88.3\end{array}$ & $\begin{array}{l}19.7 \\
16.8 \\
29.1\end{array}$ & $\begin{array}{l}49.3 \\
54.9 \\
23.3\end{array}$ & $\begin{array}{r}0.4 \\
1.1 \\
14.6\end{array}$ \\
\hline $\begin{array}{l}\text { Kaffir Corn........... } \\
\text { Ground Kaffir Corn Heads } \\
\text { Sorghum Seed......... } \\
\text { Milo Maize Seed....... } \\
\text { Broom-corn Seed....... } \\
\text { Millet Seed............ }\end{array}$ & $\begin{array}{l}90.1 \\
86.4 \\
87.2 \\
91.0 \\
87.2 \\
87.9\end{array}$ & $\begin{array}{l}5.2 \\
4.2 \\
4.5 \\
4.9 \\
4.6 \\
7.1\end{array}$ & $\begin{array}{l}44.3 \\
42.4 \\
61.1 \\
44.8 \\
42.2 \\
48.5\end{array}$ & $\begin{array}{l}1.4 \\
1.2 \\
2.8 \\
1.3 \\
1.5 \\
2.5\end{array}$ \\
\hline 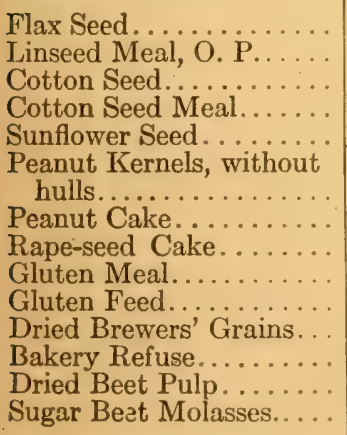 & $\begin{array}{l}90.8 \\
90.2 \\
89.7 \\
93.0 \\
91.4 \\
92.5 \\
89.3 \\
90.0 \\
90.5 \\
90.8 \\
91.3 \\
87.0 \\
91.6 \\
79.2\end{array}$ & $\begin{array}{r}20.6 \\
30.2 \\
12.5 \\
37.6 \\
14.8 \\
25.1 \\
42.8 \\
25.3 \\
29.7 \\
21.3 \\
20.0 \\
7.0 \\
4.1 \\
4.7\end{array}$ & $\begin{array}{l}17.1 \\
32.0 \\
30.0 \\
21.4 \\
29.7 \\
13.7 \\
20.4 \\
23.7 \\
42.5 \\
52.8 \\
32.3 \\
55.5 \\
64.9 \\
54.1\end{array}$ & $\begin{array}{r}29.0 \\
6.9 \\
17.3 \\
9.6 \\
18.2 \\
35.6 \\
7.2 \\
7.6 \\
6.1 \\
2.9 \\
6.0 \\
4.8 \\
\cdots \\
\cdots\end{array}$ \\
\hline $\begin{array}{l}\text { Cow's Milk..... } \\
\text { Skim Milk..... } \\
\text { Buttermilk... . . } \\
\text { Whey......... . }\end{array}$ & $\begin{array}{r}12.8 \\
9.4 \\
9.9 \\
6.2\end{array}$ & $\begin{array}{l}3.4 \\
2.9 \\
3.8 \\
0.6\end{array}$ & $\begin{array}{l}4.8 \\
5.3 \\
3.9 \\
5.0\end{array}$ & $\begin{array}{l}3.7 \\
0.3 \\
1.0 \\
0.2\end{array}$ \\
\hline
\end{tabular}




\section{AVERAGE VALUE FEED STUFFS.}

\begin{tabular}{|c|c|c|c|c|}
\hline \multirow{2}{*}{ NAME OF FEED } & \multirow{2}{*}{ 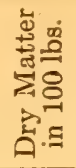 } & \multicolumn{3}{|c|}{$\begin{array}{l}\text { Digestible Nut- } \\
\text { rients in } 100 \text { lbs. }\end{array}$} \\
\hline & & $\begin{array}{l}\text { Crude } \\
\text { Protein }\end{array}$ & $\begin{array}{c}\text { Carbo- } \\
\text { hy- } \\
\text { drates }\end{array}$ & Fat \\
\hline $\begin{array}{l}\text { Meat Scrap.... } \\
\text { Meat and Bone Meal.... } \\
\text { Dried Blood............ } \\
\text { Tankage............. }\end{array}$ & $\begin{array}{l}\text { Lbs. } \\
89.3 \\
94.0 \\
91.5 \\
93.0\end{array}$ & $\begin{array}{l}\text { Lbs. } \\
66.2 \\
36.7 \\
60.8 \\
50.1\end{array}$ & $\begin{array}{l}\text { Lbs. } \\
\cdots \\
5.5 \\
\cdots\end{array}$ & $\begin{array}{r}\text { Lbs. } \\
13.4 \\
10.6 \\
2.5 \\
11.6\end{array}$ \\
\hline 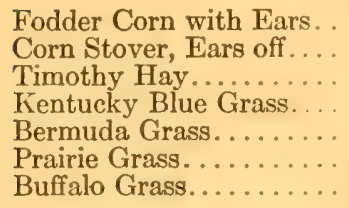 & $\begin{array}{l}57.8 \\
59.5 \\
86.8 \\
86.0 \\
92.9 \\
90.8 \\
85.0\end{array}$ & $\begin{array}{l}2.5 \\
1.4 \\
2.8 \\
4.4 \\
6.4 \\
3.0 \\
3.0\end{array}$ & $\begin{array}{l}34.6 \\
31.2 \\
42.4 \\
40.2 \\
44.9 \\
42.9 \\
42.0\end{array}$ & $\begin{array}{l}1.2 \\
0.7 \\
1.3 \\
0.7 \\
1.6 \\
1.6 \\
1.6\end{array}$ \\
\hline $\begin{array}{l}\text { Red Clover............ } \\
\text { Alsike Clover.......... } \\
\text { White Clover........ } \\
\text { Sweet Clover..... }\end{array}$ & $\begin{array}{l}84.7 \\
90.3 \\
90.3 \\
92.1\end{array}$ & $\begin{array}{r}7.1 \\
8.4 \\
11.5 \\
11.9\end{array}$ & $\begin{array}{l}37.8 \\
39.7 \\
42.2 \\
36.7\end{array}$ & $\begin{array}{l}1.8 \\
1.1 \\
1.5 \\
0.5\end{array}$ \\
\hline 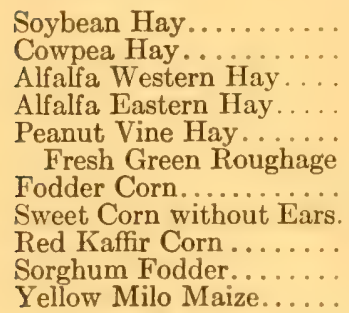 & $\begin{array}{l}88.2 \\
89.5 \\
93.2 \\
93.6 \\
92.4 \\
20.7 \\
20.0 \\
18.4 \\
20.6 \\
16.8\end{array}$ & $\begin{array}{r}10.6 \\
5.8 \\
11.1 \\
11.7 \\
6.7 \\
1.0 \\
0.7 \\
0.8 \\
0.6 \\
1.1\end{array}$ & $\begin{array}{r}40.9 \\
39.3 \\
39.1 \\
40.9 \\
42.2 \\
11.9 \\
11.6 \\
9.7 \\
11.6 \\
9.3\end{array}$ & $\begin{array}{l}1.2 \\
1.3 \\
0.6 \\
1.0 \\
3.0 \\
0.4 \\
0.4 \\
0.4 \\
0.3 \\
0.3\end{array}$ \\
\hline $\begin{array}{l}\text { Kentucky Blue Grass.... } \\
\text { Timothy............. }\end{array}$ & $\begin{array}{l}34.9 \\
38.4\end{array}$ & 1.5 & $\begin{array}{l}19.7 \\
19.9\end{array}$ & $\begin{array}{l}0.8 \\
0.6\end{array}$ \\
\hline $\begin{array}{l}\text { Wheat Forage......... } \\
\text { Rye Forage.......... } \\
\text { Oat Forage........... } \\
\text { Barley Forage....... }\end{array}$ & $\begin{array}{l}22.7 \\
23.4 \\
25.0 \\
21.0\end{array}$ & $\begin{array}{l}1.7 \\
2.1 \\
2.6 \\
1.9\end{array}$ & $\begin{array}{l}12.0 \\
14.1 \\
11.0 \\
10.4\end{array}$ & $\begin{array}{l}0.4 \\
0.4 \\
0.6 \\
0.3\end{array}$ \\
\hline 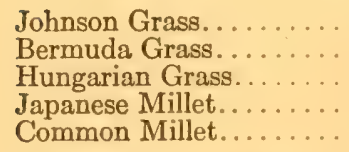 & $\begin{array}{l}25.0 \\
28.3 \\
28.9 \\
25.0 \\
20.0\end{array}$ & $\begin{array}{l}0.6 \\
1.3 \\
2.0 \\
1.1 \\
0.8\end{array}$ & $\begin{array}{l}13.7 \\
13.4 \\
15.9 \\
13.6 \\
11.0\end{array}$ & $\begin{array}{l}0.2 \\
0.4 \\
0.4 \\
0.3 \\
0.2\end{array}$ \\
\hline $\begin{array}{l}\text { Fresh Green Legumes } \\
\text { Red Clover............ } \\
\text { Mammoth Red Clover... } \\
\text { Alsike Clover........... } \\
\text { Sweet Clover.......... }\end{array}$ & $\begin{array}{l}29.2 \\
20.0 \\
25.2 \\
20.0\end{array}$ & $\begin{array}{l}2.9 \\
2.0 \\
2.6 \\
2.5\end{array}$ & $\begin{array}{r}14.9 \\
9.1 \\
11.4 \\
8.4\end{array}$ & $\begin{array}{l}0.7 \\
0.2 \\
0.5 \\
0.4\end{array}$ \\
\hline 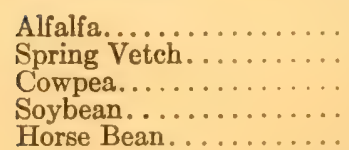 & $\begin{array}{l}28.2 \\
15.0 \\
16.4 \\
24.9 \\
15.8\end{array}$ & $\begin{array}{l}3.6 \\
1.9 \\
1.8 \\
3.1 \\
2.3\end{array}$ & $\begin{array}{r}12.1 \\
6.6 \\
8.7 \\
11.0 \\
7.3\end{array}$ & $\begin{array}{l}0.4 \\
0.2 \\
0.2 \\
0.5 \\
0.2\end{array}$ \\
\hline
\end{tabular}




\section{AVERAGE VALUE FEED STUFFS.}

\begin{tabular}{|c|c|c|c|c|}
\hline \multirow{2}{*}{ NAME OF FEED } & \multirow{2}{*}{ 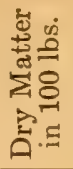 } & \multicolumn{3}{|c|}{$\begin{array}{l}\text { Digestible Nut- } \\
\text { rients in } 100 \text { lbs. }\end{array}$} \\
\hline & & $\begin{array}{l}\text { Crude } \\
\text { Protein }\end{array}$ & $\begin{array}{c}\text { Carbo- } \\
\text { hy- } \\
\text { drates }\end{array}$ & Fat \\
\hline & Lbs. & Lbs. & Lbs. & Lbs. \\
\hline Velvet Bean. & 17.8 & 2.7 & 8.4 & 0.4 \\
\hline Canada Field Pea, in bud. & 15.0 & 2.6 & 6.8 & 0.3 \\
\hline Barley and Vetch....... & 20.0 & 2.1 & 6.5 & 0.3 \\
\hline Barley and Peas......... & 20.0 & $2: 1$ & 9.1 & 0.4 \\
\hline $\begin{array}{l}\text { Oats and Peas......... } \\
\text { Roots and Tubers: }\end{array}$ & 20.3 & 1.8 & 10.2 & 0.4 \\
\hline Potato................ & 20.9 & 1.1 & 15.7 & 0.1 \\
\hline Common Beet. & 11.5 & 1.2 & 7.9 & 0.1 \\
\hline Mangel. . & 9.1 & 1.0 & 5.5 & 0.2 \\
\hline Sugar Beet. & 13.5 & 1.3 & 9.8 & 0.1 \\
\hline Falt Turnip. & 9.9 & 0.9 & 6.4 & 0.1 \\
\hline Carrot. & 11.4 & 0.8 & 7.7 & 0.3 \\
\hline Rutabs & 11.4 & 1.0 & 8.1 & 0.2 \\
\hline Artichok & 20.5 & 1.3 & 14.7 & 0 \\
\hline Sweet Potato & 28.9 & 0.8 & 22.9 & 0 . \\
\hline Cassava... & 34.0 & 0.8 & 28.9 & 0.2 \\
\hline Miscellaneous: & & & & \\
\hline Acori & 44.7 & 2.1 & 34.4 & 1.7 \\
\hline Appl & 22.2 & 0.8 & 16.5 & 0 . \\
\hline Cabbag & 10.0 & 2.3 & 5.9 & 0.1 \\
\hline Field Pu & 9.1 & 1.0 & 5.8 & 0.2 \\
\hline Garden Pumpkin. & 19.2 & 1.4 & 8.3 & 0 . \\
\hline Purslane. . & 9.0 & 2.0 & 4.5 & 0.1 \\
\hline
\end{tabular}

\section{FEEDING STUFFS CONTAINING BONE BUILDER}

\begin{tabular}{|c|c|}
\hline NAME OF FEED & $\begin{array}{l}\text { Ash } \\
\text { Per Cent. }\end{array}$ \\
\hline 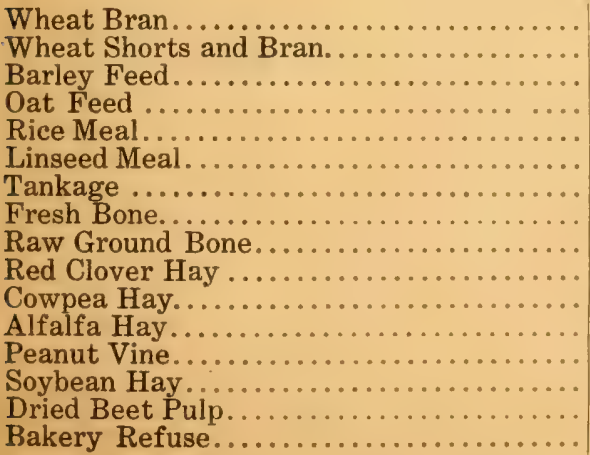 & $\begin{array}{r}6.2 \\
5.6 \\
4.4 \\
5.3 \\
8.1 \\
5.5 \\
15.9 \\
22.8 \\
64.4 \\
6.2 \\
14.2 \\
10.6 \\
10.8 \\
7.0 \\
4.5 \\
10.1\end{array}$ \\
\hline
\end{tabular}




\section{Definition of Feed Terms}

DRY MATTER-That portion of a feeding stuff which remains after all the water or moisture has been expelled by heat.

DIGESTIBLE NUTRIENTS-That portion of the dry matter which can be digested by the animal and does not pass off through the bowels as excrement. Feeding stuff is of various degrees of digestibility-regardless of the composition. So you should keep this fact in mind, as the indigestible portion is of no value in producing results.

PROTEIN-That part of the digestible nutrients which goes to the formation of lean meat, ligaments, bones, hair, skin and the casein (or curd) of milk. It is generally believed, also, that protein may be, and many times is, converted into the fat found in milk. The basis of protein is nitrogen, hence the protein elements are frequently termed the nitrogenous parts of the food. They are also called albuminoids.

CARBOHYDRATES-That part of the digestible nutrients which is the primary source of sustaining animal heat and furnishing the energy for keeping the animal mechanism in operation. They are composed of the woody fiber of the plant and grain, and the starch, sugar, gums, etc., and in the published tables of chemical analyses, are usually subdivided into the terms crude fiber, which is the least digestible portion of feeding stuffs, and nitrogen-free extract, so-called because it does not contain any nitrogen.

ETHER EXTRACT-That portion of the digestible nutrients which may be dissolved out of the food stuffs by ether. It is frequently called crude fat. It can be used by the animal for maintaining the body temperature, and for this purpose is from 2.2 to 2.5 times more efficacious than the carbohydrates. It is maintained, by some, that the fat in the milk comes, largely, from the crude fat in the food, but it has been demonstrated that it is not absolutely necessary for this purpose.

\section{Sow's Loss of Teats}

The sow that loses one or two of her teats by failure to supply milk thru them by reason of spoiled udder is an injury that decreases her value for breeding purposes. Where you hava a very valuable sow as a breeder, it is quite a serious loss, if she has two or three dry teats. 
The teat that is destroyed of its natural function of furnishing milk, most frequently occurs in the following manner:

About farrowing time, by reasun of too strong feeding, the sow's udder accumulates too much milk and the little pigs have more than they want at this time, while but a few days old, the milk thus remaining in the udder until it congests and inflammation sets in with fever, the udder becomes swollen, gathered and hard.

The fever is accompanied with constipation generally; which increases the trouble. Each teat is an outlet for the milk of its separate section of the udder and only this compartment of the udder is reached by this individual teat. If not relieved of this milk, it infects the cells of the udder and destroys their usefulness thereafter and the teat becomes dry because of no supply of milk.

Also the loss may occur by a sow having ten or twelve good teats to start with and only have a small litter, then a portion of the teats are not used by the suckling pigs, the milk in the udder sometimes dries up without injury, yet there is occasionally too much milk left, which forms a gathering and inflammation thus spoiling the teat and the loss of it permanently. Each pig usually has his own teat, which he regularly applies to for his milk ration.

Prevention is always easier and therefore better than a cure. Cut down the feed ten days before due to farrow and watch for any enlarged udder before farrowing, feed lightly for ten days after farrowing so as not to force milk production greater than the pigs can use, after two weeks they can usually take care of all the sow can furnish on full feed.

If the udder, or any teat section of it, shows signs of enlargement from too much milk before farrowing or afterwards, it should be milked out with the fingers. This is not easy and requires patience and should be milked gently so as to keep the sow quiet. She soon becomes aware that it relieves her and scemingly invites it.

Placing hot water-soaked heavy bath towels that retain the heat, over the udder, will be helpful. Using water as hot as you can bear your hand in for bathing it and gently knead the udder with the hand, so as to decrease the hard matter and apply turpentine and vaseline. If she has young pigs, allow them to suckle so as to get all of the milk out possible. You can use acetate of lead, half an ounce; tincture of arnica, two ounces; water, one quart. Bathe three times daily with hot water and 
apply the lotion after each bathing. Give from one to two ounces of Epsom salts; follow this by giving ten grains of nitrate of potassium in a little water three times a day. If matter should form when it breaks inject water into it to clean it out, then inject carbolic acid, one dram; water half a pint. Clean the parts out twice a day with a little of this, if the parts become hard or caked, rub on iodine one dram and vaseline, one ounce. Do this twice a week until the part becomes soft or the hardness disappears.

There are exceptional cases where sows have, at time of farrow, one or more what are termed "blind teats." These are small without any show of an udder connected with them, while the balance of the teats may be all right. It is claimed that a sow inherits them. We have articles from other veteran, successful, experienced breeders in this issue on this line, which will be well for young breeders to study carefully and use their own intelligence in applying to the cases that they may have to deal with.

\section{Proper Age to Breed Gilts}

This question is asked quite frequently by young breeders and sometimes by men who have been in the business quite a while. Perhaps every breeder has his opinion, but some of them do not always carry out their belief. It has been well determined that a gilt bred at about one year old or a little later is more apt to do better and to raise larger litters, especially without injury to her own growth than if bred earlier. In an article in the December issue of the Swineherd a big type breeder states that he was of the opinion that breeding gilts too young was very largely the cause of decreasing the size of the litters, that he had never had any trouble in having large litters with both medium and the big type Poland-Chinas, but his gilts were always over a year old before breeding them. We give you the following from Ed. Klever, in reference to breeding gilts, which should be of benefit to every breeder, as he has had forty years of experience and is a close observer of results :

"The above question has been referred to me for answer by the editor, and I will say from my experience and observation of a good many years in the breeding business that the proper age to breed Poland-China gilts is when 11 or 12 months of age. They certainly should not be bred before they are this old for the best results of litter and the gilt. Yet many breeders breed them at 9 to 10 months 
of age, but very few will justify or approve of too early breeding. When bred at 9 to 10 months of age they will farrow at a little over a year old. Some of our very best brood sows have been bred at 9 and 10 months. But when we breed them at that age and raise spring litters of pigs we should keep them in good, strong breeding flesh, and after the litter is weaned we always continue to grow the sow until time to breed her again in the fall.

"Don't turn a gilt out with a lot of old sows after raising her first litter. She will fare badly and get nothing but cuffs from the old sows when she ought to be well cared for and thereby take on growth. It is not necessary that she should be fattened, but it is that she should be grown. It requires good feeding to do this to keep her in good, strong, full, smooth flesh. Then she will also be able to raise a large litter and be at her best as a brood sow.

"Therefore, I conclude that for the best purposes, taking into consideration the litter and gilt's individual improvement, that she should be bred at 11 or 12 months old, generally speaking. This should be the rule, and if the exception is made of younger breeding, the very best care should be given to insure success."

\section{Feeding Pigs Just Farrowed}

Frequently it occurs that for some reason little pigs just farrowed are deprived of milk from the mother, sometimes by her death, other times because she has no milk to give them, without which they would soon starve unless fed.

An easy way of feeding is to take a shallow tin plate, pour fresh cow's milk a half inch deep; the little pigs will push their nose against the bottom of the plate and suck up the milk. If it was a couple of inches deep they could not breathe and would soon choke up. It is the best plan of feeding them with a shallow plate when so young. If you have a sow that is just suckling pigs about the same age you can sometimes put them to her as foster mother.

\section{Best Bone-Making Feed}

Wheat bran, wheat feed (shorts and bran), oat feed, including hulls, are leaders as bone builders. Rice bran, rice meal, soy bean, linseed cake meal, molasses beet pulp, dry blood, tankage, alfalfa hay and clover hay are also good, while raw ground bone or meat and bone meal are the two highest. 
Peanut vine without nuts is on a par with cowpea and alfalfa. This will give parties an opportunity of making selections to increase the bone-making material and will show that for cheapness alfalfa and clover hay or cowpea vine and peanut vine are among the cheapest of the bone-making feeds.

The brood sow needs to grow a strong and healthy litter. Protein and ash should therefore be prominent factors in her feed; young ones require a higher proportion of this substance than old ones. A sole corn diet lacks in protein and ash and for that reason tends toward small litters and weak-boned pigs. As before suggested one-half to two-thirds of the ration may consist of alfalfa or other legume hay. A ration found successful is one-half alfalfa hay (third cutting), one-half grain made up of six parts barley, three parts shorts and one part tankage.

\section{The Feeder}

The responsibility for the outcome of the pig crop rests very largely with the feeder. The farmer or breeder who buys a good sow bred to a great boar and then neglects to give proper care and attention to feeding and developing his pigs is wasting money. Too many farmers have an idea that the hog must rustle for himself; while we appreciate a good rustler and hustler, it is necessary to guide and provide feed to enable the best, greatest and most profitable developments.

To show you that it is a loss of good work and money to buy choice stock and then virtually desert it, is just the same as buying a good farm and then neglecting it. The good, enterprising, thinking farmer who is both progressive and aggressive not only maintains his farm, but builds it up, increases its ability to produce, making it more valuable and more profitable all the time. This is in compliance with nature's laws, progress, growth, improvement. It takes work to do this, but when you put your mind into it and your interests are served thereby, work is really a pleasure.

To show the difference in treatment and feeding we call attention to the photographic views of the two pigs of the same litter, one fed by an aggressive, progressive, ambitious boy, who had the seed of enterprise planted in him by the suggestions of his teacher, and who has shown his father the way to do it. He has not done this with costly feeds, but with plain, profitable feeds, and the result is so emphatic that no man can help realizing its value. 
This is a day of intense farming, and intense feeding is a member of the family. The limits of improvement are the limits of your achievements. They virtually have no limit if you have none. When we look at what Edison has done by thought in his line, and Burbank in his line, it shows that the young farmer can have just as great a future as he chooses to make. The man who does not give his pigs the care and thus produce the development and the good rosuits should not be engaged in the breeding business. He should be only too glad to accept the superior results that others have obtained and follow instead of lead. One of the necessary things to start on the right road should be the brain. Get it to working and thinking. The thinking farmer will be the successful one. Of course it is necessary to not only have fine spun theories, but keep the mind going in a practical way, step by step, until you have accomplished your dream of better things.

A half century ago the human race in the large cities in many countries and even in our own country were subject to dreadful contagious diseases and plagues, but today they are handled with sanitary rules and requirements that have cut down the losses to the minimum. Nothing shows this more completely than the city of Havana, a disease breeding, infected city, where it was dangerous to life during nine months of the year until the United States army took possession of the city and made it a model of cleanliness and as healthy as other cities, showing the benefits of observing sanitary measures.

For the health of the hogs, sanitary rules must be better observed. First, we must have strong constitutioned hogs, which we can have by better feeding. Next, we must have their houses and lots properly cleansed and air slacked lime under the troughs, around the corners and throughout them. They must be supplied with pure water and clean feed, then the condition of their bowels should be watched with closeness, for constipation is the beginning of trouble. Don't permit it. Give laxative food, good pastures, careful feeding, and never make a sudden radical change of food; do it gradually and it will be for best results for the health of your hogs.

It pays to take the best of care. This progressive era in farming demands intense farming and feeding.

\section{Revolution in Hog Feeding}

The benefit derived from feeding brood sows alfalfa or clover hay is the greatest evolution in hog feeding that has occurred in many years. It must 
prove worth many thousands of dollars to the farmers of the United States.

Those who are unacquainted with the advantages realized by the brood sow and litter from feeding two-thirds of the ration in alfalfa or clover hay, cut at the right time to contain the best strength in the leaves, are dumbfounded when they are shown the results. It is almost impossible for them to believe that such could be the case.

The sow does exceptionally well, while the unfarrowed litter of pigs that are being developed are of strong constitution, average large number to the litter and are apparently a week to ten days old when farrowed, compared with pigs from sows that have had mostly a corn diet.

We believe that nothing in the feed line within the last twenty years is as important as the discovery of the value of alfalfa and clover hay as a feed for brood sows. It opens a new era not only as to the worth and the strength of the animals but the cheapness of maintaining and feeding compared with a concentrated corn feed. The methods of feeding are given in this book. It may be fed when ground into a meal and mixed with other feed, or run through a cutter and wet with water, or as hay. Hogs will soon learn to eat it out of the rack. It gives added values to alfalfa and clover as hog feed. Its importance is on a par with silage for cows.

\section{Difficult Farrowing}

If the sow has been kept in proper condition with laxative food there should be no trouble in farrowing. However, there are times when a case of difficult farrowing comes up from a sow that is out of condition. At other times from a gilt, because of her close build, rendering forceps necessary to remove the litter. Then you want them badly.

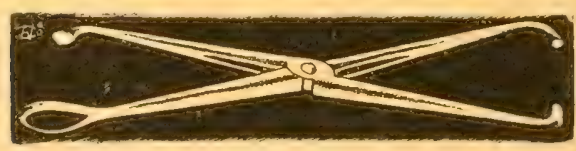

Thousands of breeders in all parts of the country have tested and used the "Barbers Pig and Lamb Forceps" with the greatest of success. In many cases they have been successful after trying six to nine different kinds, and when the sow is in the last agony, have secured a pair of Barbers and relieved her. They are therefore recognized as superior to all. They can always be had at $\$ 1.50$ a pair sent postage paid by addressing, American Swineherd, Chicago, Ill. 


\section{How to Grow an 800-lb. Sow}

This matter of growing an $800-1 b$. sow is a much simpler affair today than it was five years ago. At that time an $800-1 b$. sow was almost a novelty because a comparatively small number of Big Type were being bred and grown. Now everyone has them, no matter what stock they are from or what they would really weigh on the scales. It's our experience that they are much more rare than a person would think at first. But there is a lot of them and they are not all in one place or one community either.

Now our experience has taught us to get a gilt that will weigh 800 lbs, at maturity, she must have that kind of a mother and a sire that is really in the 1,000-pound scale class. Also, she must have a lot of them in the second, third and fourth or fifth crosses, or as far back as you want to go.

Pick your gilt with a good broad head and rather heavy ear. Don't be particular that she has a heavy full crest, but be sure she has a good strong back with a fairly well sprung rib, but not so she looks as broad as she is long. That kind can't get past 500 pounds no matter how hard they try. Get a fairly low ham and a good, strong middle and heart girth. Now give her plenty of length. Not good length but exceptional length. And then put her up in the air so high she looks a little stilty. You can feed any of them to the ground, but you have to breed them up into the air. Have a bone that is considerably heavier than looks pretty on that sized gilt. Have a good, strong pastern joint as short as possible. But don't expect a half-inch pastern on a 14-inch leg. Have a good coat of hair just a little coarse and if she has a few stray spots it won't make her a bit smaller, although it won't make her any larger, either.

Now take this gilt and put her with twenty-five others if you want to. That kind don't need babying or pampering or new milk. They will take care of themselves. Give this gilt all the whole oats she will eat at all times if you want the greatest growth. Keep her on good pasture in the summer and feed alfalfa in some form in the winter if you can. Make her slop ration of wheat middlings 8 parts, oat middlings 8 parts, tankage 1 part, and oil meal 1 part. Give her corn if you are in a corn country. What good would hogs be to our grain belt farmer if they can't eat corn without hurting them. But don't make her feed all corn. Don't overfeed at any time and don't let her stop growing, but don't make her grow over one pound or a little better each day. When this sow is twelve or thirteen months old she should farrow her first litter and with proper care should raise two litters each year and keep growing all the time. This means a judicious and liberal cross of the feed basket.

So pick your gilt with good stretch and bone. Give us that and a good back and good legs and we'll make a hog out of her. Feed her growing rations without fattening. Give a ary warm place to sleep in and good pasture to exercise in and if she has the stuff in her pedigree she will weigh 800 pounds at three years old, at least seventy-five times out of one hundred. But remember, you can't get big harvests if you plant inferior seed. And also remember, the demand for good seed is always such that it takes a nice little pile of money to get very much of it. But it pays. Look at the sow and not your pocketbook and your pocketbook will look better in the future. When a breeder once sees an 800 -pound sow he is never satisfied until he owns one. 


\section{INDEX}

Alfaifa

Page

Balanced Ration ..................... 10

Best Bone Making Feed................... 59

Bone Making Feed.................... 10

Breeder's Method, by Cassell............. 48

Brood Sow, by Dorr..................... 23

Brood Sow, by Keller................ 45

Brood Sow, by Marker................. 26

Brood Sow, by Mugg.................. 39

Brood Sow, by Sefrit................. 50

Brood Sow, by Williams................ 34

Brood Sow Pointers..................... 44

Brood Sow, the Mortgage Lifter............ 2

Brood Sows, Eating Alfalfa Hay........... 14

Changing Feed ...................... 18

Comparison of Farm Animals.............. 19

Danger Signals ....................... 15

Definition of Feed Terms................ 56

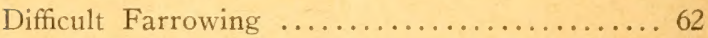

Easy Farrow ...................... 43

Feed Value Tables................53, 54, 55

Feeder ...........................6 60

Feeding Pigs Just Farrowed............... 59

Handling Sow After Breeding............. 7

Hog House, by James................. 30

Improvement in Hog Business............ 1

Individual Sow House, by Lovejoy............ 28

Milk in Feed....................... 20

Money in Water...................... 20

Non-Breeding Sow Treatment.............. 41

Overfeeding the Sow.................. 9

Paralysis ........................ 22

Prolificacy ........................ 3

Proper Age to Breed Gilts, by Klever........ 58

Revolution in Hog Feeding............... 62

Sows Disowning Pigs.................. 19

Sow's Loss of Teats.................... 56

Treatment for Aborting Sows............. 42

Winn's Show Pigs..................... 28

Winter Temperature for Pigs............. 28 


\section{Make More Money With Hogs}

This largely involves the feed question, as feed is the principal cost of producing pork. It is not only what to feed, but how to feed, to enable the feeder to get the most.out of hogs, in the quickest time, at least cost.

It is a proven fact, two or more feeds, properly combined, are better than any one of the same fed singly. The general farmer, without knowing it, wastes one-fourth of the feed given his hogs, which is a total loss. This is where the balanced ration comes to the relief of the wise feeder. It is not what the pig eats, but what he digests and assimilates, that makes the profits.

Expert feeding means success. It teaches you how to cheapen the feed, how to get greater growth and gain over the common way of feeding, from the same feed given, and how to get more pounds of pork from a bushel of corn.

The AMERICAN SWINEHERD is progressive and aggressive. It instructs you in the wisdom gathered by experience from the greatest experts in their line, being successful, practical feeders, managers and caretakers of the herd. It is a specialist in producing pork from pighood to the pork market. This is the era of advancement and adoption of up-to-date, scientific methods in the hog business. There is a new crop of experience grown monthly.

The American Swineherd was founded 34 years ago by the present editor. We have subscribers who have taken the paper for over 25 years. Hundreds of them on renewing say: "Do not let us miss a copy." One party writes: "I found information out of a single sample copy, that, put to practice, saved me more than the cost of your paper for 10 years." No matter how many papers you take, you need the money making information the Swineherd gives you. Another party writes: "I believe the Swineherd the most valuable publication on our list, which includes 16 of the best, dealing with all branches of stock raising, dairying and farming."

SPECIAL OFFER: For $\$ 1.00$ we will mail you the American Swineherd for two years. This is the cheapest expert help you can hire. It pays and is economy to take advantage of the experience that brought the other fellow success.

We will also give you as a premium, a copy of the "Hog Doctor," 68-page book of home remedies. Address,

\section{AMERICAN SWINEHERD}

\section{Old Colony Bldg.}

Chicago, Illinois. 


\section{LIBRARY OF CONGRESS}

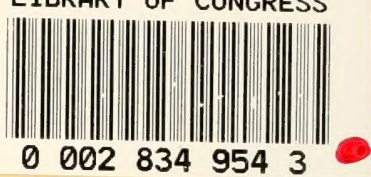

